\title{
WestVirginiaUniversity
}

THE RESEARCH REPOSITORY @ WVU

Graduate Theses, Dissertations, and Problem Reports

2012

\section{New Abutment Angle Concept for Underground Coal Mining}

Ihsan Berk Tulu

West Virginia University

Follow this and additional works at: https://researchrepository.wvu.edu/etd

\section{Recommended Citation}

Tulu, Ihsan Berk, "New Abutment Angle Concept for Underground Coal Mining" (2012). Graduate Theses, Dissertations, and Problem Reports. 3578.

https://researchrepository.wvu.edu/etd/3578

This Dissertation is protected by copyright and/or related rights. It has been brought to you by the The Research Repository @ WVU with permission from the rights-holder(s). You are free to use this Dissertation in any way that is permitted by the copyright and related rights legislation that applies to your use. For other uses you must obtain permission from the rights-holder(s) directly, unless additional rights are indicated by a Creative Commons license in the record and/ or on the work itself. This Dissertation has been accepted for inclusion in WVU Graduate Theses, Dissertations, and Problem Reports collection by an authorized administrator of The Research Repository @ WVU.

For more information, please contact researchrepository@mail.wvu.edu. 


\title{
New Abutment Angle Concept for Underground Coal Mining
}

\author{
Ihsan Berk Tulu
}

Dissertation submitted to the

Benjamin M. Statler College of Engineering and Mineral Resources

at West Virginia University

in partial fulfillment of the requirements

for the degree of

\author{
Doctor of Philosophy \\ in \\ Mining Engineering
}

\author{
Keith A. Heasley, Ph.D., Chair \\ Christopher Bise, Ph.D. \\ Yi Luo, Ph.D. \\ Brijes Mishra, Ph.D. \\ Department of Mining Engineering \\ West Virginia University \\ Gabriel Esterhuizen, Ph.D. \\ Office of Mine Safety and Health Research \\ National Institute for Occupational Safety and Health
}

\section{Morgantown, West Virginia \\ 2012}

Keywords: Abutment angle, LaModel, ALPS, ARMPS, pillar design 


\section{ABSTRACT \\ New Abutment Angle Concept for Underground Coal Mining}

\section{Ihsan Berk Tulu}

In the Analysis of Retreat Mining Pillar Stability (ARMPS), Analysis of Longwall Pillar Stability (ALPS) and LaModel programs, the magnitude of the abutment loading adjacent to a gob area is calculated using an "abutment angle" concept, and the extent of the abutment loading is determined as solely a function of depth from an empirically derived equation. However, the latest in-situ stress measurements of abutment loading performed in the United States and Australia have shown that there can be significant deviations in the measured abutment magnitude and extent as compared to the predicted values from the empirical formulas used in ARMPS, ALPS and LaModel.

In this dissertation, stress measurements from U.S. and Australian mines were back analyzed by using analytical and numerical methods to investigate the measured abutment extent and loading. Ultimately, it was determined that the original empirical abutment extent formula in conjunction with the original ALPS square-decay stress distribution function was supported by the case histories reviewed in this dissertation. Also, for depths less than $900 \mathrm{ft}$, the average $21^{\circ}$ abutment angle was supported by the case histories; however, at depths greater than $900 \mathrm{ft}$, the abutment angle was found to be significantly less than $21^{\circ}$ and should be calculated with a new proposed equation. 


\section{To my wife Delal;}




\section{ACKNOWLEDGMENTS}

First of all, I would like to express my gratitude to my supervisor Dr. Keith A. Heasley whose knowledge, leadership, professionalism, attention to detail and hard work have set an example I hope to match some day. He provided me direction, technical support and became more of a mentor than a professor throughout my graduate study. I want to thank to him for giving me the opportunity to work with him and studying in West Virginia University.

I would like to thank my committee members Dr. Gabriel Esterhuizen, Dr. Yi Luo, Dr. Brijes Mishra and Dr. Christopher Bise for their supports and invaluable suggestions during this research.

I would like to thank David Hill from Strata Engineering plc. of Australia, Dr. Christopher Mark from MSHA for their invaluable contributions and suggestions during this research.

I would like to thank Dr. Ismet Canbulat from Anglo Coal Australia whose hard work, knowledge, professionalism, determination and friendship have set an example for me and I would like to thank him for his support since our first met in Johannesburg South Africa.

Most of all I would like to thank my dearest, beautiful, lovely wife Delal for her encouragement, patience, support and making everything more meaningful and beautiful for me. 


\section{Table of Contents}

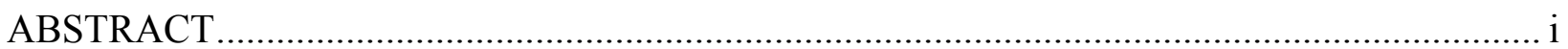

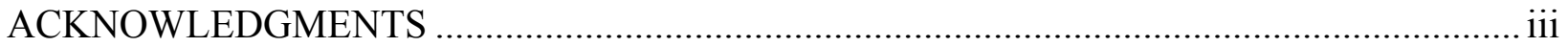

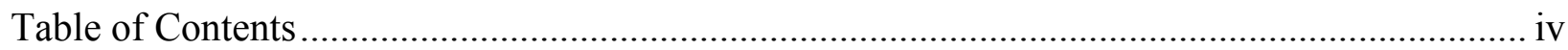

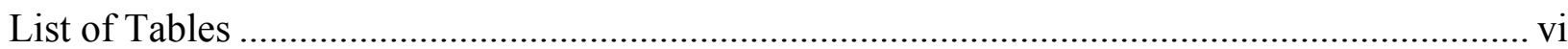

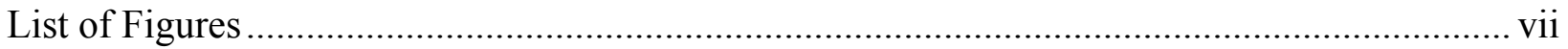

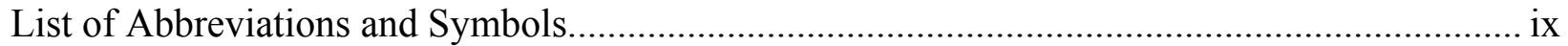

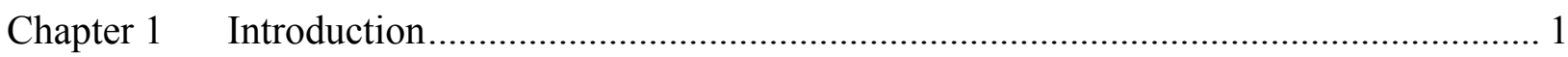

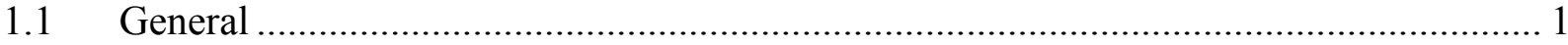

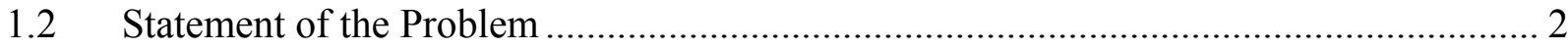

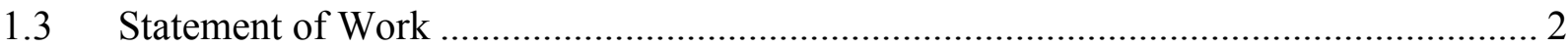

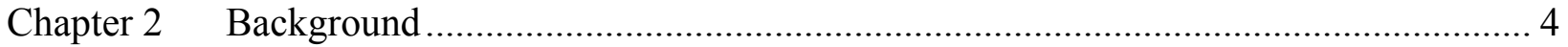

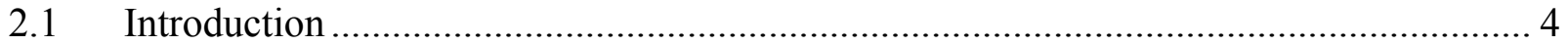

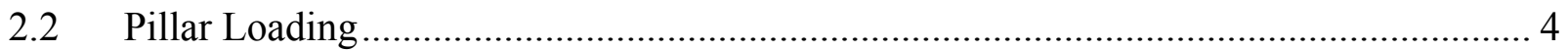

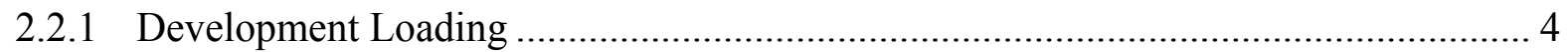

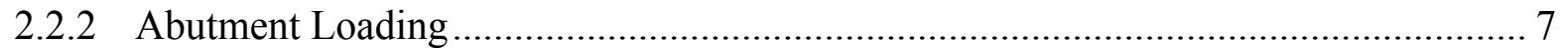

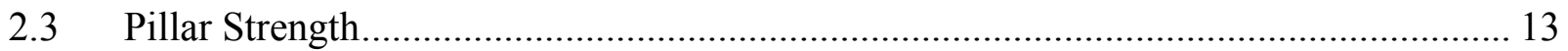

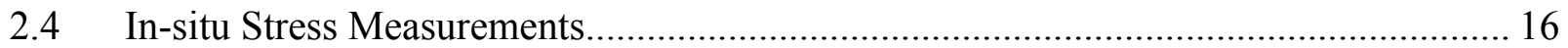

2.4.1 Field Measurements for Pillar Strength................................................................. 18

2.4.2 Field Measurements for Abutment Loads ……………………............................. 22

2.4.3 Original Stress Measurements for Abutment Extent ................................................. 22

2.4.4 Original Stress Measurements for Abutment Angle................................................. 24

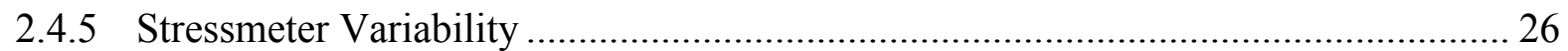

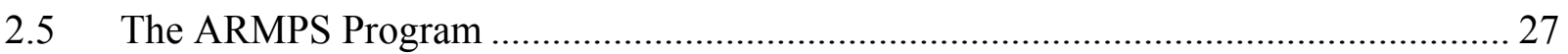

2.6 LaModel and Calibration for Deep Cover Mining .................................................... 30

2.6.1 Calibrating the LaModel Program for Deep Cover Pillar Retreat Coal Mining ........ 31

2.6.2 The Verification of the Deep Cover Retreat Mining Calibration Method .................. 31

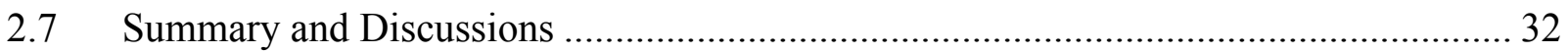

Chapter 3 Re-Analysis of Abutment Load ........................................................................... 34

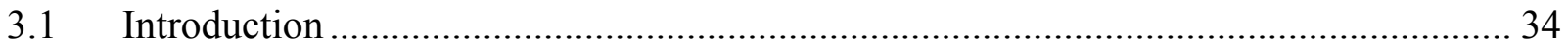

3.2 Stress Measurement Database .............................................................................. 34

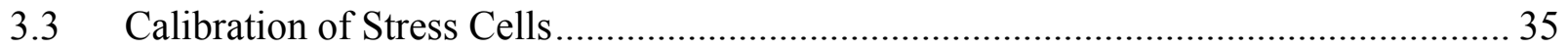


3.3.1 Comparison of the Calibration Methods ………....................................................... 36

3.4 Abutment Extent and Abutment Angle Calculation .................................................... 38

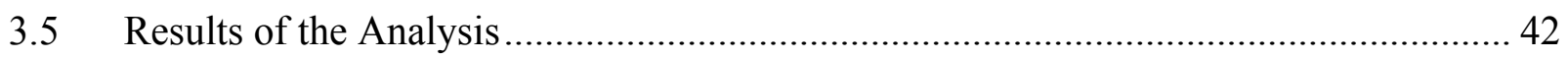

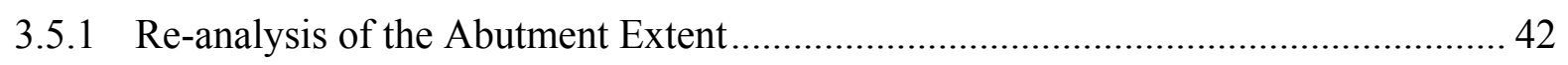

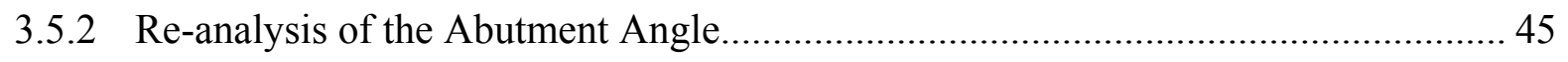

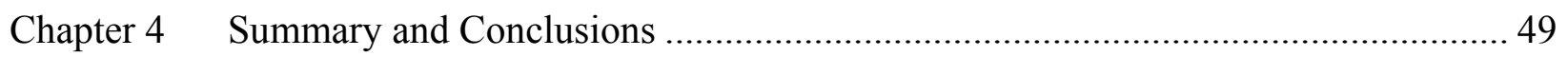

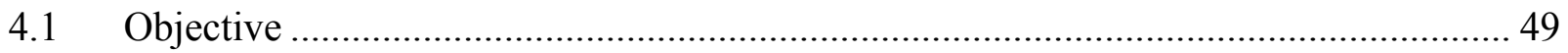

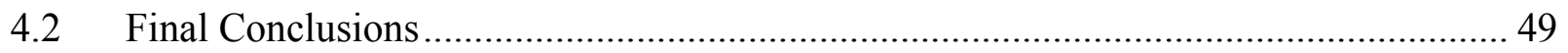

4.3 Ideas for Additional Research ............................................................................... 50

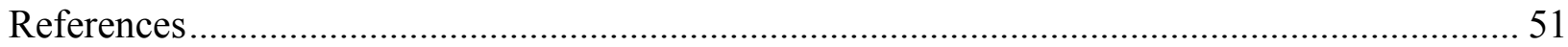

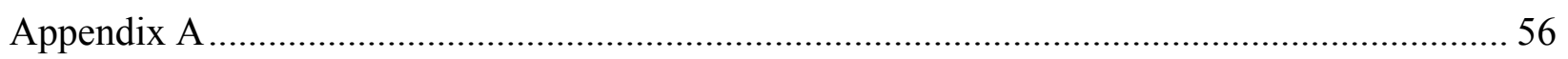




\section{List of Tables}

Table 2.1 Stress measurement database (Mark and Iannacchione, 1992) ............................... 19

Table 2.2 Summary of the stress measurements used by Peng and Chiang (1984)................... 23

Table 2.3 Summary of the stress measurements used by Mark (1992)................................... 24

Table 2.4 Recommended ARMPS stability factors (after Chase et al., 2002).......................... 28

Table 2.5 Abutment extent observed in Western U.S. mines (Haramy et al., 1989; Lu, 1982)... 33

Table 3.1 Summary statistics of the present stress measurement database .............................. 34

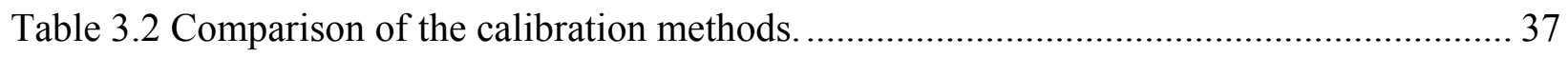

Table 3.3 Comparison of abutment angles back calculated using LaModel and Square Decay

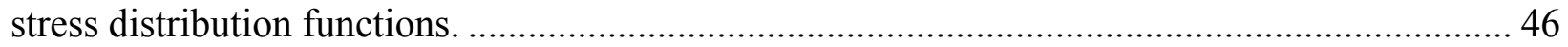

Table 3.4 Comparison of abutment angles back calculated by using Square Decay and Calibrated

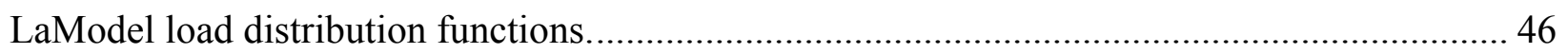

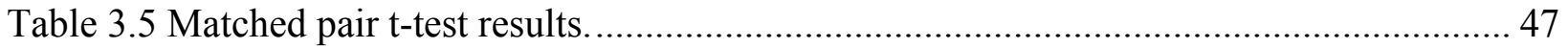

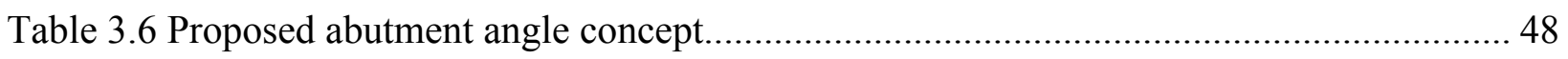

Table A.1 Stress measurement case histories where multiple stress changes were monitored

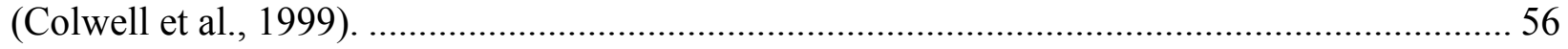

Table A.2 Stress measurement case histories where only the final full side-abutment stress

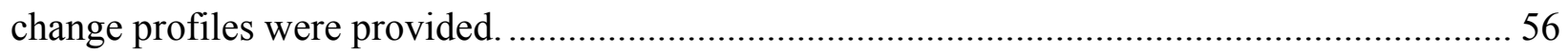

Table A.3 Supplementary field measurement data (Mark, 1992; Colwell et al., 1999)............. 57 


\section{List of Figures}

Figure 2.1 Loading models for development panel a) Tributary area, b) Pressure arch (after

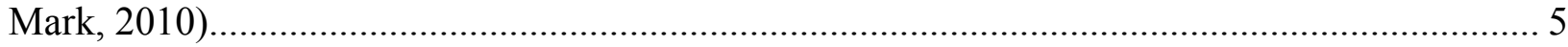

Figure 2.2 Pressure arch factor change with overburden depth/panel width ratio (after Mark, 2010) 6

Figure 2.3 Superposition of the stresses on a pillar influenced by two adjacent entries (after Hoch et al., 1992). 7

Figure 2.4 Overburden movement resulting from longwall mining (after Peng, 2008) ............... 8

Figure 2.5 (a) Redistribution of stress, (b) Linear stress decrease in gob (after Wilson, 1982).... 9 Figure 2.6 General representation of subcritical load model (after Whittaker and Frith, 1987). . 10 Figure 2.7 Abutment angle concept (after Mark, 1992). 11

Figure 2.8 Gob and yield pillar simulated as point forces of different strength inside the crack (after Kramer, 1996). 13

Figure 2.9 Vertical stress distribution (a) Wide pillars, (b) Limit of roadway stability, (c)

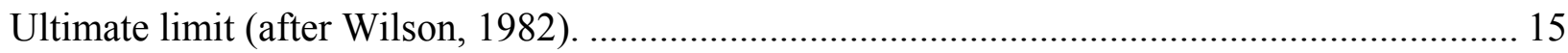

Figure 2.10 Vibrating Wire Stress (VWS) meter (after Geokon, 2004).................................. 17

Figure 2.11 Borehole Pressure Cell (BPC) (after Babcock, 1980)........................................ 17

Figure 2.12 Pillar strength formulas obtained from stress measurements compared with existing

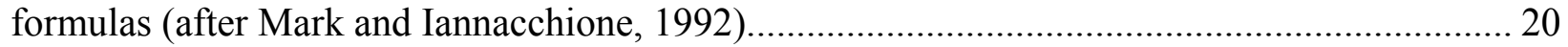

Figure 2.13 Best-fit curves for in-situ pillar strengths (after Maleki, 1992)............................ 21

Figure 2.14 Stress decay with distance (after Mark, 1992)............................................... 25

Figure 2.15 In-situ stress measurements and Bieniawski formula. ...................................... 26

Figure 2.16 Recommended ARMPS SF from the 2002 deep cover study (after Chase et al., 2002). 28

Figure 2.17 Abutment angles back calculated from Australian mines (after Collwel et al., 1999). 29

Figure 2.18 Recommended ARMPS SF from the 2010 deep cover study (after Mark, 2010).... 30 Figure 2.19 The LaModel safety factors for the calibration verification case histories (after

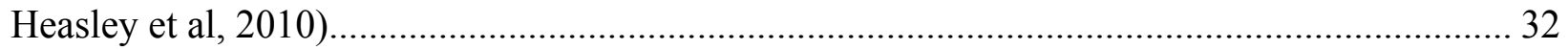

Figure 3.1 Loading history of the stress cells (after Colwell et al., 1999)............................... 36 
Figure 3.2 Typical stress change data from a two entry mine ........................................... 39

Figure 3.3 Analytical stress distribution functions. ..................................................... 42

Figure 3.4 Extent of the abutment zone containing $90 \%$ of the abutment load........................ 43

Figure 3.5 Extent of the abutment zone containing 50\% of the abutment load......................... 44

Figure 3.6 Comparison of the $\mathrm{D}_{0.9}$ extent of the abutment zone back calculated from square

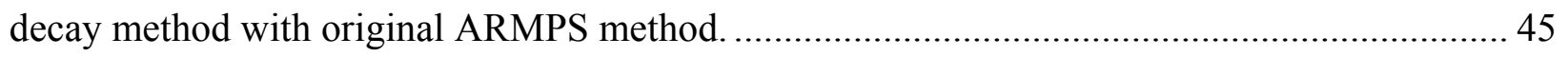

Figure 3.7 Abutment angles calculated using the square decay model. .................................. 48 


\section{List of Abbreviations and Symbols}

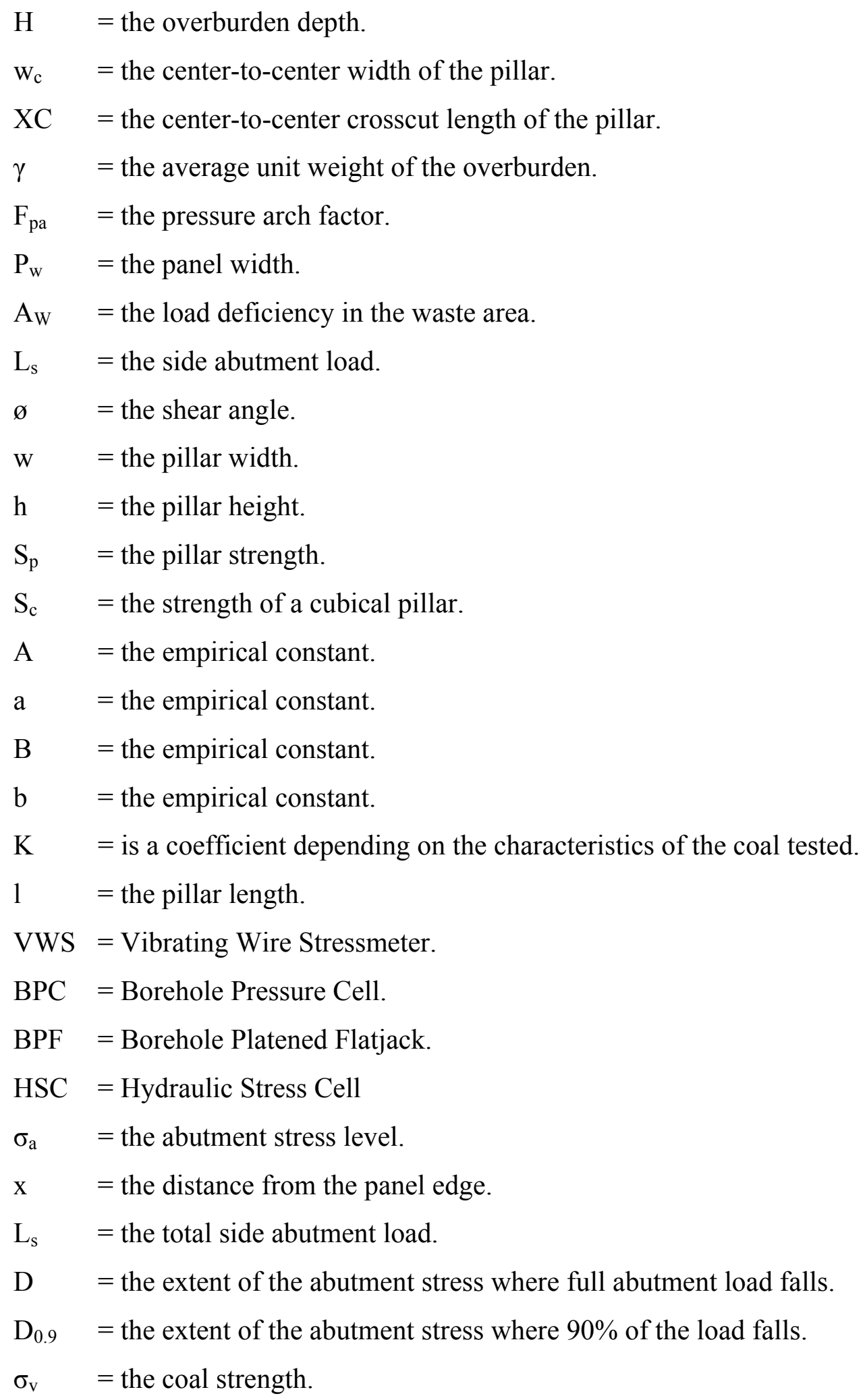




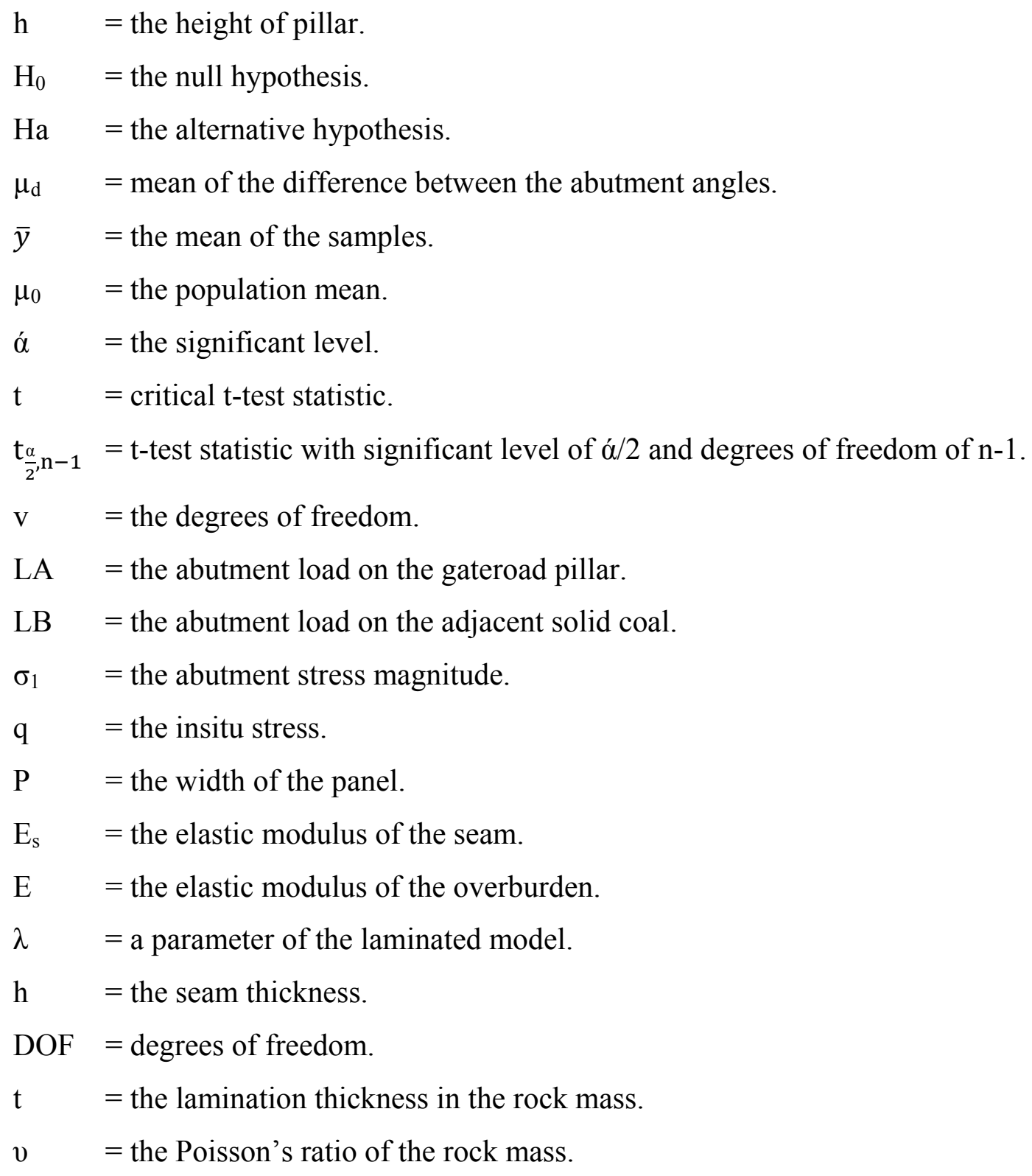




\section{Chapter 1 Introduction}

\subsection{General}

If a mining engineer wants to ensure the global stability of an underground coal mine, there are several pillar design methods available. In the U.S. coal mining industry, the Analysis of Longwall Pillar Stability (ALPS) and the Analysis of Retreat Mining Stability (ARMPS) are programs used to design coal mine pillars (Mark, 1992; Mark, 2010). These two design programs perform three functions: 1) predict the overburden load distribution on the pillars, 2) predict the load bearing capacity of the pillars and 3 ) calculate the stability factor.

In order to predict the overburden load distribution, it is required to calculate the abutment loads. If one wishes to calculate the abutment load, it is necessary to estimate the three major components of it: 1) magnitude, 2) functional distribution and 3) the extent of the abutment load. In the ALPS and ARMPS programs, the magnitude of the abutment loading adjacent to a gob area is calculated using an "abutment angle" concept, the abutment load is distributed by using a square-decay load distribution function, and the extent of the abutment loading is determined as solely a function of depth from an empirically derived equation.

Numerical models are also commonly used to design coal pillars. With regard to the numerical models, the success and accuracy of an analysis depends entirely on the accuracy of the input parameters. In the U.S. coal mining industry, the LaModel program is generally the selected numerical model for pillar design. LaModel has default properties for most of the input parameters that were developed to give "reasonable" output for "average" mining conditions. Using the calibration method recommended by Heasley et al. (2010), the first approximation of the overburden loads are calibrated to mirror those used in ALPS and ARMPS; however, the flexure of the laminated overburden and the relative stiffness/strength of the seam elements still determine the ultimate distribution of the overburden loads. In the recommended calibration method for LaModel, it was believed that the empirical equations for calculating the magnitude and extent of the abutment load as used in ALPS and ARMPS where the best available methods

for determining these critical overburden loading values; and therefore, similar calculations were implemented in the LaModel calibration method. 


\subsection{Statement of the Problem}

The in-situ stress measurement studies used to develop the empirical abutment extent equation (Peng and Chiang, 1984) used in ALPS, ARMPS and LaModel consist of eight cases where mining took place before 1984. Similarly, the abutment angle concept was developed by Mark (1992) from six cases from four mines where mining took place before 1992. Present mines have significantly different panel dimensions than the mines where stress measurements were originally collected and used to derive the original empirical abutment extent formula and the average $21^{\circ}$ abutment angle. However, in the intervening years, there has not been any updated or better approach proposed to predict abutment extent or abutment angle. However, the latest in-situ stress measurements of abutment loading performed in Australia (Colwell et al., 1999) and the United States (Vandergrift and Conover, 2010; Larson and Whyatt, 2012) showed that there can be significant deviations in the measured abutment load magnitude and extent as compared to the predicted values from the old empirical formulas used in ALPS / ARMPS and LaModel.

In this dissertation, it is proposed to analyze the in-situ stress measurements collected at as many old and modern field sites as possible and to back calculate the abutment angle and abutment extent for each of these sites. And then, as a result of the field site back calculations, to generate a database of abutment angles and abutment extent values to compare with the current methods. It is the objective of this dissertation to improve the current empirical $21^{\circ}$ abutment angle concept and abutment extent equation from the most recent in-situ stress measurements representing the current mining conditions.

\subsection{Statement of Work}

In-order to evaluate the current empirical abutment extent and abutment angle equations used by ALPS/ARMPS and the calibrated LaModel program, a database of stress measurements from different coal fields were collected. This stress measurement database consists of field data collected from both the U.S. and Australian mines. The U.S. data includes some of the cases which were originally used by Peng and Chiang (1984) and Mark (1992) to derive the current empirical equations. Also, five Australian data sets that were provided by Strata Engineering Plc are included. The remaining data sets were collected from previously published reports and papers. With all of the case history information, the following analysis steps were performed: 
1) Calibration of the stress meter responses.

2) Analysis of the abutment extent.

3) Analysis of the abutment angle.

During the analysis of the abutment extent and abutment angle, two different analytical load distribution functions were used:

1) Square decay stress distribution function.

2) Laminated overburden model stress distribution function.

With the result from this detailed analysis, a database of abutment angle and abutment extent values for a range of mining conditions and geometries was formed. These data base values were then used in a statistical analysis to investigate the effect of the overburden depth and panel width on the abutment extent and abutment angle. Finally, the results of this statistical analysis were used to evaluate the existing abutment extent and abutment angle concepts to identify the weakness of the current methods and ultimately to improve these existing concepts. 


\section{Chapter 2 Background}

\subsection{Introduction}

Pillar design is the most crucial ground control component to ensure the global stability of a panel. In general, the design of a pillar for mining operation consists of three basic steps: estimation of the load applied to pillar, estimation of the strength of the pillar and determination of the stability factor (Mark, 1992).

\subsection{Pillar Loading}

\subsubsection{Development Loading}

Pillar loads can be divided into two categories; development load and abutment load. For predicting development load, the "tributary area theory" has been used successfully by many researchers for both room-and-pillar and longwall mines (Mark, 1992; Mark and Chase, 1997; Chase et al., 2002; Wilson, 1982; King and Whittaker, 1971; Salamon and Munro, 1967). The tributary area theory states that the overburden load above any pillar and half the entry on each side is applied to the pillar itself (Figure 2.1.a), and the expression for the development load is:

$$
\mathrm{L}_{\mathrm{D}}=\mathrm{H} \times \mathrm{w}_{\mathrm{c}} \times \mathrm{XC} \times \gamma
$$

where:

$$
\begin{aligned}
& \mathrm{H}=\text { the overburden depth. } \\
& \mathrm{w}_{\mathrm{c}}=\text { the center-to-center width of the pillar. } \\
& \mathrm{XC}=\text { the center-to-center crosscut length of the pillar. } \\
& \gamma=\text { the average unit weight of the overburden. }
\end{aligned}
$$

Mark (1987) ran a series of finite element models to evaluate the tributary area theory for use in longwall pillar design. He concluded that the accuracy of the theory decreased as the extraction ratio increased. During the comparison of the development loads calculated by the tributary area theory and the finite element models, he changed the extraction ratio up to $50 \%$. Finally, he concluded that the development loads calculated by the tributary area theory were within $10 \%$ of the development loads calculated by the finite element model. 
Tributary area loading was implemented into the ALPS program (Mark, 1992). Also, previous versions of ARMPS program used the tributary area theory to predict development loads (Mark and Chase, 1997; Chase et al., 2002). After the Crandall Canyon mine disaster, NIOSH started new research to improve the safety of retreat room-and-pillar mining under deep cover by further enhancing the ARMPS program (Mark, 2010). At the beginning of the research, 200 new case histories (primarily deep cover) from 35 different mines were added to the ARMPS database (Mark, 2010). Then, to reduce the overburden loads on the deep cover development pillars as estimated by ARMPS, a pressure arch concept was investigated (Figure 2.1.b).
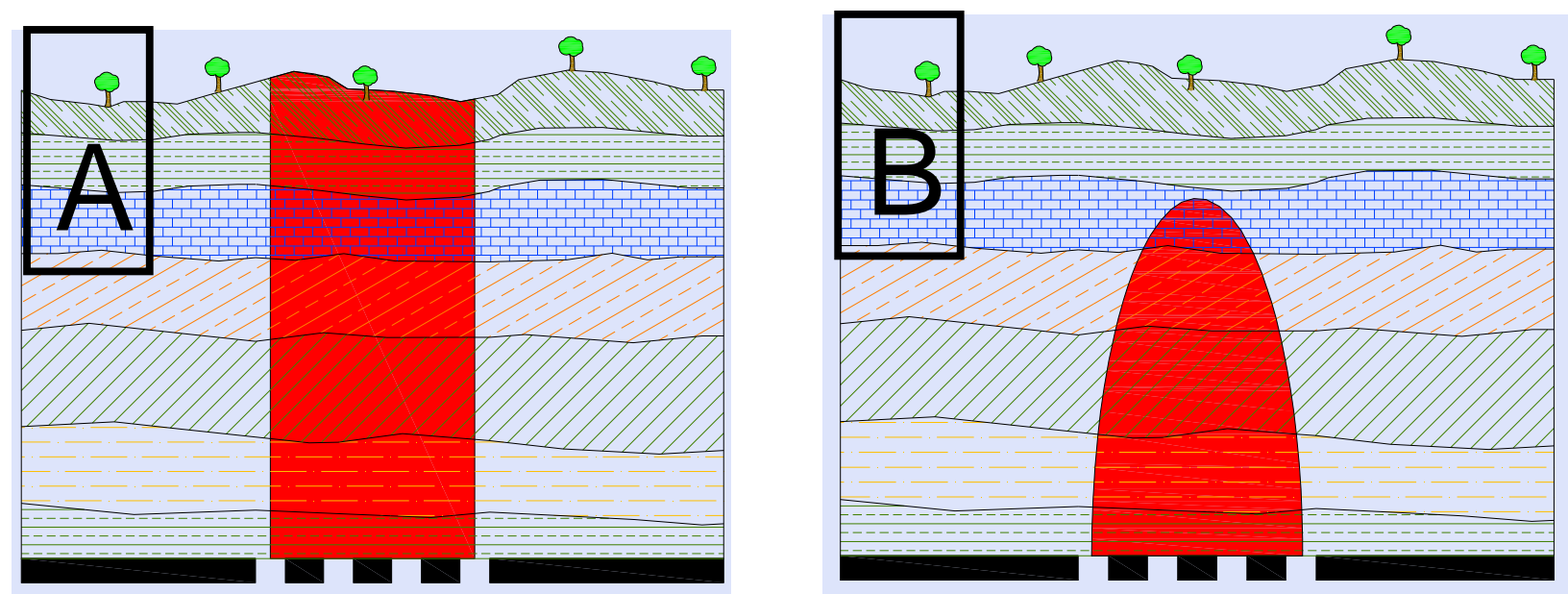

Figure 2.1 Loading models for development panel a) Tributary area, b) Pressure arch (after Mark, 2010)

Initially, three different pressure arch loading functions (linear, elliptic, and logarithmic) with various parameters were analyzed. Ultimately, the pressure arch equation which allowed a constant stability factor with depth and which provided the optimum separation between the successful and unsuccessful cases in the database was the logarithmic function (Equation 2.2). In the pressure arch concept, the tributary area loading that is carried by the development pillars is reduced by the pressure arch factor (Figure 2.2). The remaining overburden load is transferred to the adjacent solid coal abutment pillars.

$$
\mathrm{F}_{\mathrm{pa}}=1-\left(0.28 \times \ln \left(\frac{\mathrm{H}}{\mathrm{P}_{\mathrm{w}}}\right)\right)
$$

where:

$\mathrm{F}_{\mathrm{pa}}=$ the pressure arch factor. 
$\mathrm{H}=$ the overburden depth.

$\mathrm{P}_{\mathrm{w}}=$ the panel width.

(This formula only applies when the overburden depth of cover is greater than the panel width plus $80 \mathrm{ft}$.)

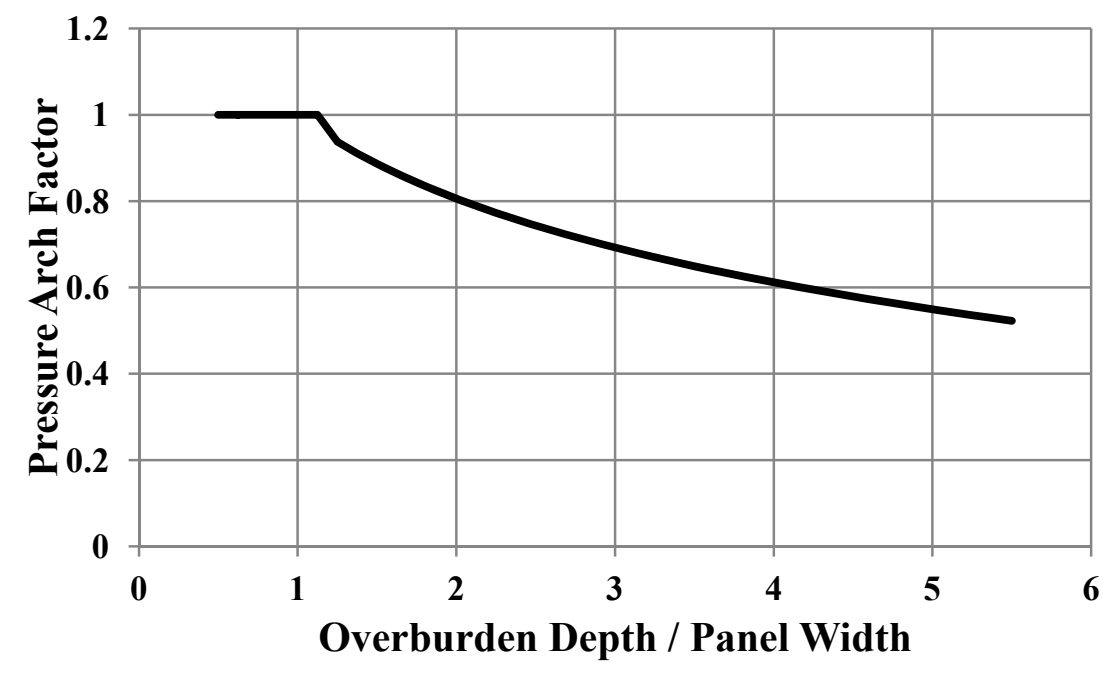

Figure 2.2 Pressure arch factor change with overburden depth/panel width ratio (after Mark, 2010).

Some researchers have used closed-form analytical solutions of elliptical, circular and rectangular openings inside an infinite elastic medium to estimate the stress distribution and development load magnitude on the pillars (Coates, 1981; Hoch et al., 1992; Kramer, 1996; Brady and Brown, 2004). The closed-form analytical equations of a single opening were used to generate the stress concentration around an individual entry. Then, by using the principle of superposition, the total stress concentration on each pillar was calculated (Figure 2.3). However, these analytical stress functions need to be coupled with failure models (Barron, 1992; Brady and Brown, 2004) or empirical yield formulas (Kramer, 1996) to overcome the singularity encountered at the edge of the pillar rib. 


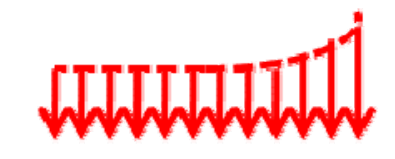

Stress influence from left

entry

Stress influence from right entry
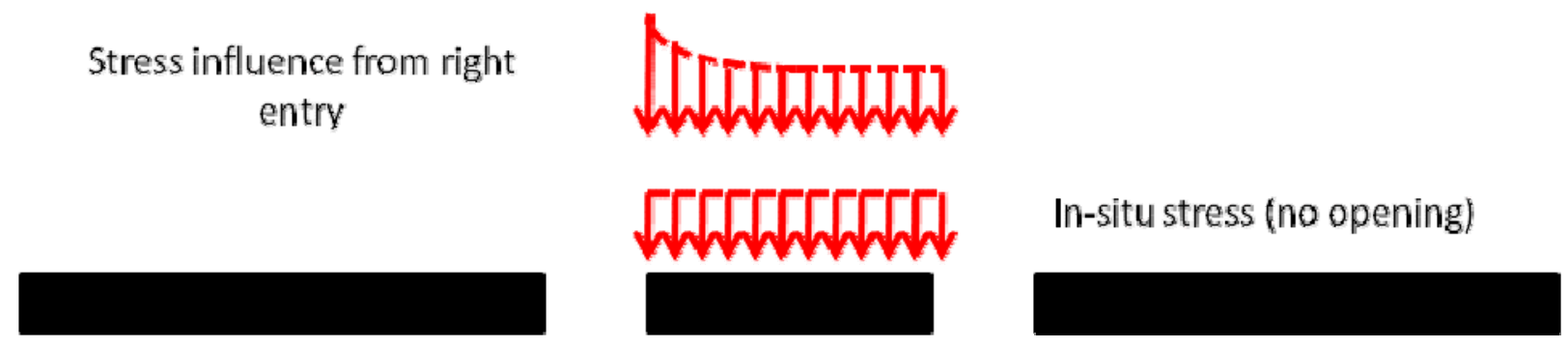

Figure 2.3 Superposition of the stresses on a pillar influenced by two adjacent entries (after Hoch et al., 1992).

Coates (1981) indicated that numerical methods are more adequate than analytical methods because they can take the three-dimensional geometry and the various overburden and rock mass properties into account. The accuracy of a numerical analysis (in regard to pillar design) depends on the suitability of the numerical method and the appropriateness of the input parameters. Simply using mechanical material properties gathered from laboratory tests of rock samples is typically not sufficient to produce realistic, or accurate, rock mass models. Calibration of the model input parameters with respect to reality is typically needed (Peng, 2008; Skiles and Stricklin, 2009; Heasley et al., 2010).

\subsubsection{Abutment Loading}

As the coal in a panel (longwall or retreat room-and-pillar) is being extracted, bedded strata above the extracted seam start to converge. Convergence continues with the advance of the panel until strata close to coal seam (called the immediate roof) break and cave. The caved strata break into smaller rock pieces and these pieces fill the empty space originated due to mining. This caved strata is called gob or goaf. Peng (2008) indicated that the strata movement response to full extraction mining depends strongly on the location and thickness of the strong strata and the mining geometry. Peng (2008) also identified four zones of disturbance in the overburden strata in response to mining as: 1) the caved zone, 2) the fractured zone, 3) the continuous deformation zone and 4) the soil zone (Figure 2.4). 


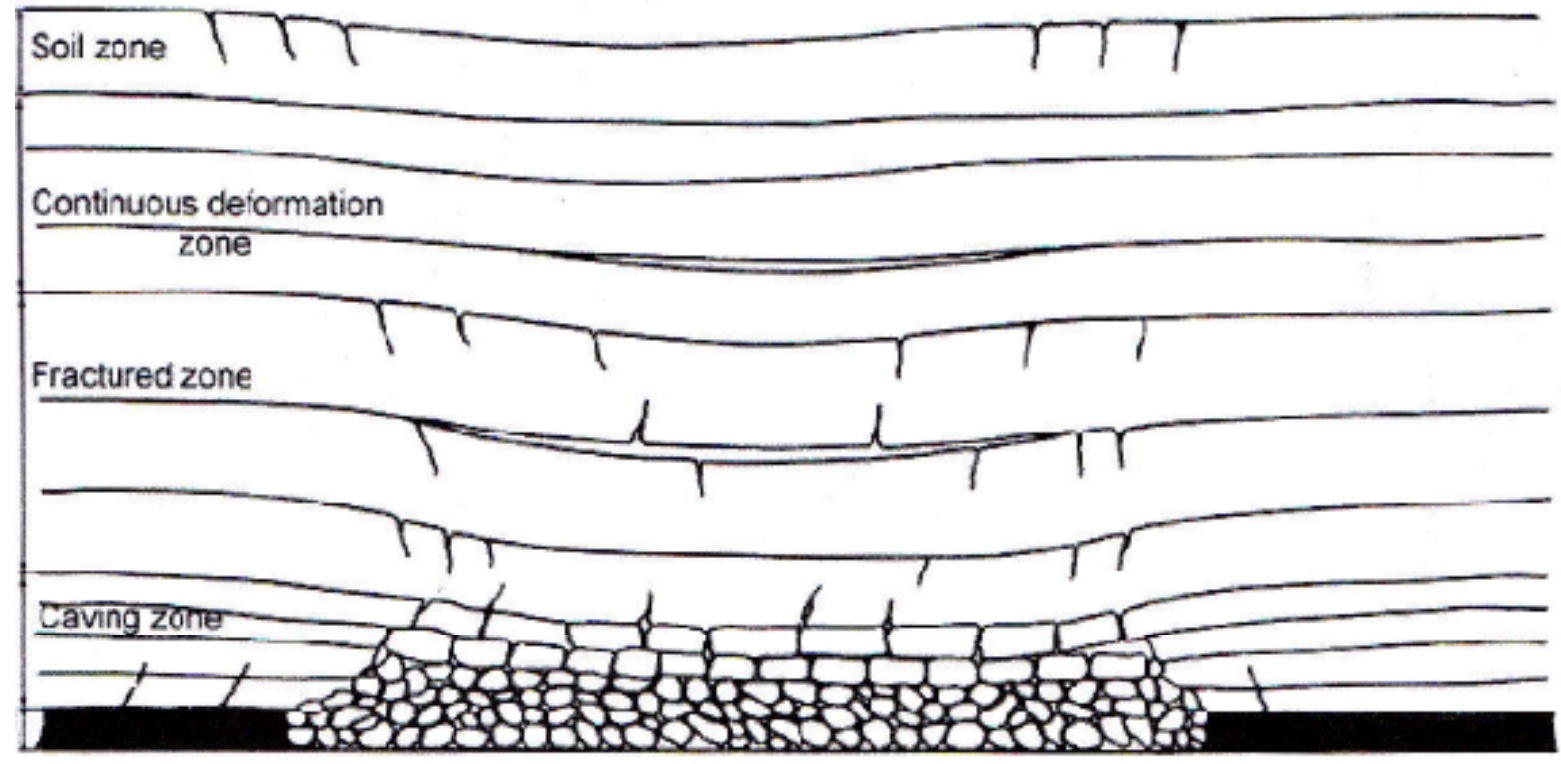

Figure 2.4 Overburden movement resulting from longwall mining (after Peng, 2008)

Load equilibrium is destroyed because of the extraction of the panel coal. Overburden load carried by the solid coal, before the panel advance, is distributed between the chain pillars, production pillars, gob and barrier pillars (or solid coal). The loads that are transferred to the adjacent pillars or solid coal are called as abutment loads.

Abutment loads are typically divided into two categories based on the location of the extracted panel relative to the pillar in question. Mark (1992) defined the "front abutment" as the abutment load coming from the active panel onto the active face area and the "side abutment" as the abutment load coming from the adjacent, previously mined panel.

The side abutment load is easier to estimate than the front abutment load, because the front abutment has to be treated in a complex three-dimensional geometry. On the other hand, the side abutment can be treated in two-dimensions (Mark, 1987). Wilson (1982) proposed an approach to predict the magnitude of the side abutment load based on the analysis of the data from British coal mines. The foundation of his approach was stress equilibrium.

Wilson (1982) emphasized that the average vertical load before mining remains constant after mining and any stress decrease in the gob (or any local area) must be balanced by an equivalent increase in load on adjacent sections (Figure 2.5.a). Based on measured roadway convergence near full-extraction mines and compaction studies of broken rock, Wilson concluded that the load on the gob increases linearly starting from zero at the rib side up to the 
in-situ load at a certain distance into the gob. Wilson (1982) presented the results of the measured maximum pressure arch study of the North of England Safety in Mines Research Committee, and based on this study, he concluded that the distance required for the gob load to return to in-situ load is between the 0.2 and 0.3 times of the overburden depth. He emphasized that the higher value of 0.3 times the overburden depth should be adopted, since this would give the greater pillar stress and error on the side of safety.

According to Wilson's approach, the total stress rise on the rib side can be represented by a triangular area if the gob width is greater than 0.6 times the overburden depth (a supercritical panel), or by a trapezoidal area if the gob width is less than 0.6 times the overburden depth (a subcritical panel) (Figure 2.5.b). The linear load increase per foot of entry is estimated by Equation 2.3 for a supercritical panel and Equation 2.4 for a subcritical panel (Wilson, 1982).
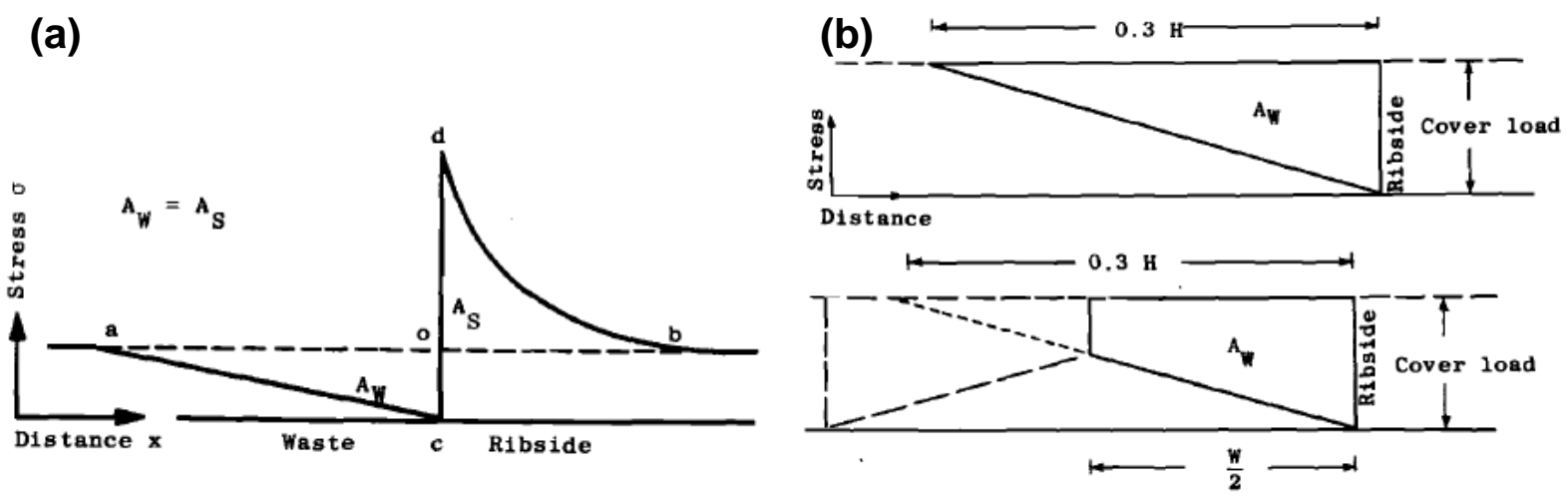

Figure 2.5 (a) Redistribution of stress, (b) Linear stress decrease in gob (after Wilson, 1982).

$$
\begin{aligned}
& \mathrm{A}_{\mathrm{W}}=0.15 \times \gamma \times \mathrm{H}^{2} \\
& \mathrm{~A}_{\mathrm{W}}=\frac{1}{2} \times \mathrm{P}_{W} \times \gamma \times \mathrm{H}^{2} \times\left(\mathrm{H}-\frac{\mathrm{P}_{\mathrm{W}}}{1.2}\right)
\end{aligned}
$$

where:

$\mathrm{A}_{\mathrm{W}}=$ the load deficiency in the waste area.

$\mathrm{P}_{\mathrm{W}}=$ the panel width.

Another analytical approach was proposed by King and Whittaker (1971). The difference between this approach and Wilson's approach is the concept of shear angle. According to Whittaker and Frith (1987) the load transferred from the gob depends on the mining depth and the subsidence profile. The subsidence profile and the magnitude of the load transferred to the chain pillars can be determined from the shear angle (Figure 2.6). King and Whittaker (1971) 
suggested $31^{\circ}$ for the shear angle for British Coal mines since this value was compatible with the established subsidence principles. According to Wilson's approach, the distance required to reach the in-situ load in the gob is 0.3 times the overburden, and this distance implies a shear angle equal to $16.7^{\circ}$. Equation 2.5 and 2.6 show the calculation for the load on the chain pillars for subcritical and supercritical subsidence profiles according to King and Whittaker's approach.

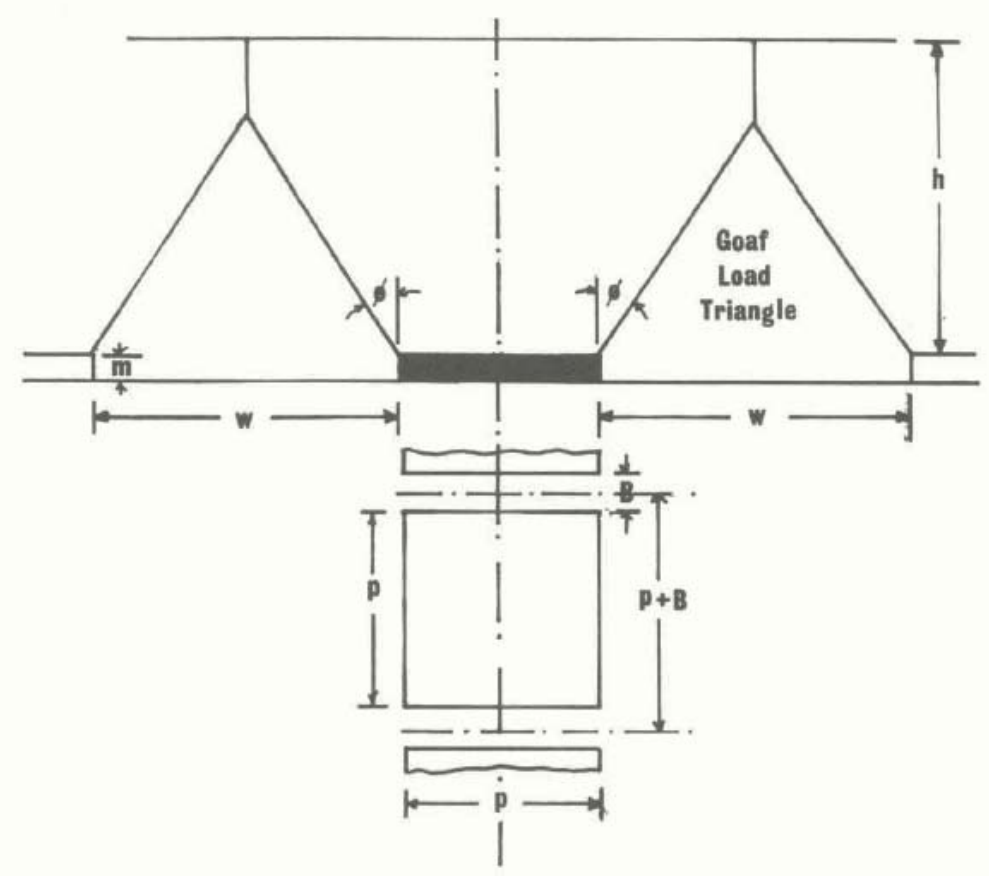

Figure 2.6 General representation of subcritical load model (after Whittaker and Frith, 1987).

For a subcritical panel where $\frac{{ }^{P_{\mathrm{W}}}}{\mathrm{H}} \leq 2 \times \operatorname{Tan} \emptyset$ :

$$
\mathrm{L}_{\mathrm{S}}=\left(\frac{\mathrm{H} \times \mathrm{P}_{\mathrm{W}}}{2}-\frac{\mathrm{P}_{\mathrm{W}}{ }^{2}}{8 \times \operatorname{Tan} \emptyset}\right) \gamma
$$

For a supercritical panel where $\frac{\mathrm{P}_{\mathrm{W}}}{\mathrm{H}} \geq 2 \times \operatorname{Tan} \emptyset$ :

$$
\mathrm{L}_{\mathrm{S}}=\frac{1}{2} \times \mathrm{H}^{2} \times \operatorname{Tan} \emptyset \times \gamma
$$

where:

$\mathrm{L}_{\mathrm{s}}=$ the side abutment load.

$\varnothing=$ the shear angle.

Choi and McCain (1980) modified the shear angle concept for U.S. longwall mines by defining a "complete displacement zone". According to Choi and McCain, in the complete 
displacement zone there would not be any further surface subsidence. This means that the gob carries the full weight of the overburden inside the zone and that the side abutment loads transferred from the gob come from the areas outside of the complete displacement zone. The complete displacement zone can be determined by the "negative angle of draw" (essentially equivalent to the shear angle). Choi and McCain (1980) suggested a negative angle of draw of $18^{\circ}$ for the Pittsburgh seam. This value is very close to the Wilson's suggestion for British coal mines.

Mark (1992) evaluated the three different methods, originally proposed by Wilson (1982), King and Whittaker (1971), and Choi and McCain (1980), to predict the side abutment loads. He summarized that all three were very similar in application using an "abutment angle" approach (see Figure 2.7); however, Mark indicated that all three methods calculated different values of the abutment angles because of different case histories. Further, Mark (1987) explained that the abutment angle should not be considered a physical reality, but as an approximation which defines the magnitude of the side abutment loading. Mark (1992) analyzed stress measurement data from five different mines and suggested an average $21^{\circ}$ abutment angle for U.S. mines.

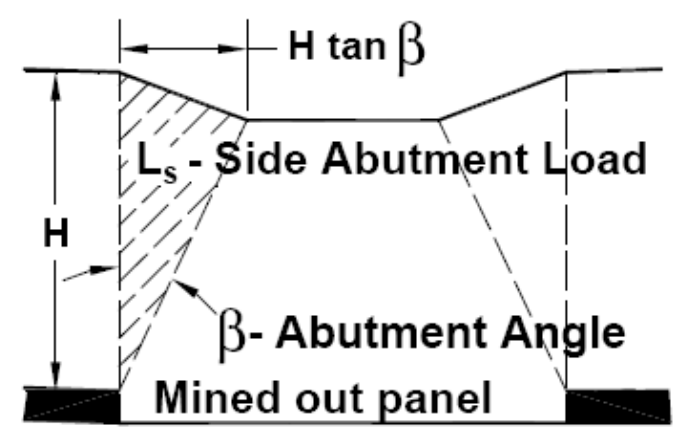

Supercritical

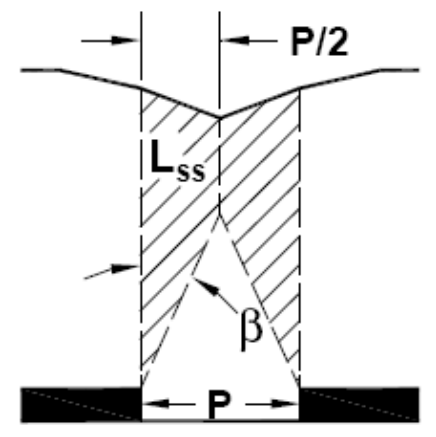

Subcritical

Figure 2.7 Abutment angle concept (after Mark, 1992).

The magnitude of the front abutment load is more difficult to determine analytically because the three dimensional geometry of the face causes a non-uniform front abutment distribution along the corners of the face. Peng and Hsiung (1984) showed that front abutment extent is not uniform across the panel based on the stress measurements. According to their study, the front abutment extent was wider at the gate road side and decreased toward the center. In the past 
because of the difficulty in predicting front abutment loads, many field measurements of front abutment loads were performed (Peng, 2006).

From mining stand point, Mark (1992) indicated that the most critical abutment loads are those experienced by the pillars at the face ends of T-junctions. When the first panel is mined, the pillars at the headgate T-junction must carry the first front abutment (headgate front abutment). As the face continues to advance, the pillar load increases until it stabilizes at a final magnitude called side abutment load (Mark, 1992). When the second panel is mined, pillars at the tailgate $\mathrm{T}$-junction carry the side abutment load from the first panel and front abutment load from the second panel (tailgate front abutment). Mark (1992) proposed to use a front abutment factor to determine the magnitude of the front abutment load applied on the chain pillars in the headgate and tailgate of longwall mines. He used measured front abutment stresses from five different mines to estimate the front abutment factors. He suggested a headgate front abutment factor of 0.5 and a tailgate abutment factor of 0.7 for U.S. longwall mines. In the ARMPS program, Mark and Chase (1997) calculated the front abutment load on the Active Mining Zone (AMZ) with a complex analytical procedure.

Kramer (1996) introduced an analytical approach for the prediction of abutment load. This analytical approach was developed based on the principles of fracture mechanics. The mine entries and longwall gob have been treated as Mode I crack in an infinite elastic medium. The gob load and yielding pillar resistance are represented by distributed forces on the surface of the crack (Figure 2.8). In order to determine the magnitude of the gob load, Kramer (1996) used the $21^{\circ}$ abutment angle. This analytical approach distributes loads based on an analytical stress distribution equation, but the abutment load magnitude is calculated from the empirical abutment angle. This method is very easy to use and quick to calculate, but it is acceptable only for simplified 2D geometries. In addition, boundary element numerical models like Mulsim (Zipf, 1992) and LaModel (Heasley, 1998) are available to simulate more complex 3D mining geometries. These models are also computationally efficient and run very fast. 


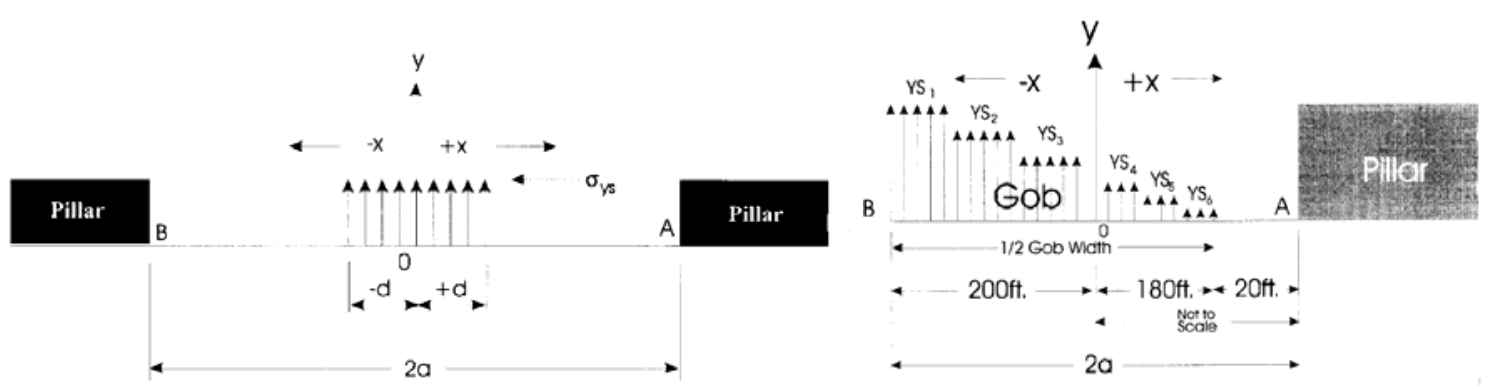

Figure 2.8 Gob and yield pillar simulated as point forces of different strength inside the crack (after Kramer, 1996).

\subsection{Pillar Strength}

In the last few decades, the strength of the coal pillar has been investigated by many researchers, and many different coal pillar strength formulas were developed. These formulas can be divided into three main categories: 1) empirical methods (Salamon and Munro, 1967; Holland and Gaddy, 1957; Bieniawski, 1981; Obert and Duvall, 1967), 2) analytical methods (Wilson, 1982; Barron, 1984), and 3) field measurement methods (Mark and Iannacchione, 1992; Maleki, 1992).

It is a general agreement among the researchers that the strength of a coal pillar increases with the pillar's width to height ratio, and empirical formulas typically represent this strength increase by following a linear (Equation 2.7) or a power (Equation 2.8) type of equation (Peng, 2008).

$$
\begin{aligned}
& S_{p}=S_{c}\left(A+B \frac{W}{h}\right) \\
& S_{p}=S_{c} \frac{w^{a}}{h^{b}}
\end{aligned}
$$

where:

$$
\begin{array}{ll}
\mathrm{W} & =\text { the pillar width. } \\
\mathrm{h} & =\text { the pillar height. } \\
\mathrm{S}_{\mathrm{p}} & =\text { the pillar strength. } \\
\mathrm{S}_{\mathrm{c}} & =\text { the strength of a cubical pillar. }
\end{array}
$$

$\mathrm{A}, \mathrm{B}, \mathrm{a}, \mathrm{b}=$ the empirical constants.

The constants of the empirical pillar strength formulas are determined from curve fitting to compressive strength data from coal specimens of various shapes and sizes. The pillar strength 
predicted by an empirical formula is treated as the average pillar stress at failure (Mark, 1987). Peng (2008) indicated that the constants of each empirical formula are different, and different constants result in different pillar strengths. Therefore, any adaptation of one of the strength formula for a certain pillar design application will give different result.

Peng (2008) reported that the first U.S. empirical coal strength formula was a linear function that is similar to equation 2.7, and it was developed in 1911 by Bunting. Then, the next formula was proposed by Greenwald in 1941. In 1957, the Holland and Gaddy (1957) formula was proposed (Equation 2.9). In equation 2.9, " $\mathrm{K}$ " is a coefficient depending on the characteristics of the coal tested. The value of the $\mathrm{K}$ can be determined from Uni-axial Compressive Strength (UCS) tests.

$$
S_{p}=K \frac{\sqrt{W}}{h}
$$

The Bieniawski pillar strength formula (Equation 2.10) has been used in U.S. for both room and pillar operations and longwall Mining (Mark, 1992). Bieniawski established the formula based on a series of 57 underground in-situ coal pillar strength tests performed in South Africa (Peng, 2008; Bieniawski, 1981). He estimated the critical size of the pillars as $3 \mathrm{ft}$ and the cubic strength of the pillar as $930 \mathrm{psi}$. He recommended a safety factor of 1.5 to 2.0 for room-and-pillar mining and 1.3 for longwall mining (Bieniawski, 1992).

$$
\mathrm{S}_{\mathrm{p}}=\mathrm{S}_{\mathrm{c}}\left(0.64+0.36 \frac{\mathrm{w}}{\mathrm{h}}\right)
$$

Early empirical formulas (Bieniawski, 1981; Holland and Gaddy, 1957; Salamon and Munro, 1967) assume that the coal pillar is square, and in a rectangular pillar the longer dimension is considered to have no effect. Peng (2008) explained two approaches developed to account for the effect of longer dimension. The first method is to include the pillar dimension into the empirical equation and the second method is to use an effective width. Mark and Chase (1997) used the first method and expended the Bieniawski formula by adding the third dimension into the empirical formula. Mark- Bieniawski pillar strength formula is shown in Equation 2.11.

$$
\mathrm{S}_{\mathrm{p}}=\mathrm{S}_{\mathrm{c}}\left[0.64+\left(0.54 \frac{\mathrm{w}}{\mathrm{h}}-\left(0.18 \frac{\mathrm{w}^{2}}{\mathrm{hl}}\right)\right)\right]
$$

where:

$1=$ the pillar length. 
Several different analytical methods have been proposed to predict the strength of coal pillars (Wilson, 1982; Barron, 1984, 1992; Salamon, 1992). The confined core concept was first proposed by Wilson (1982) for British collieries and lately updated for U.S. mines (Carr and Wilson, 1982). In this concept, Wilson divided the pillar into two zones: 1) a yield zone, and 2) an elastic core. According to Wilson, the yield zone is established at the rib of the pillar with an extent dependent on the strength of the coal, overburden depth and roof-floor properties. In the yield zone, the coal reaches its maximum possible load bearing capacity and it cannot take any more loads. Also, this zone provides confinement to the elastic core. Wilson assumed that the peak stress is encountered at the boundary between the yield zone and the elastic core, and based on this assumption, he proposed three possible vertical stress distribution scenarios. If the pillar is wide enough to have a large elastic core, the stress will decrease towards the pillar center as shown in Figure 2.9.a. As the mining continues and additional load is applied on the pillar, the average stress in the pillar core starts to increase (Figure 2.9.b). Wilson called this the "Limit of Roadway Stability". Further load applied to the pillar expands the yield zone until the pillar reaches an "Ultimate Limit" (Figure 2.9.c). After the pillar has reached the ultimate limit, it cannot take additional loads and any excess load is transferred to the next row of pillars.
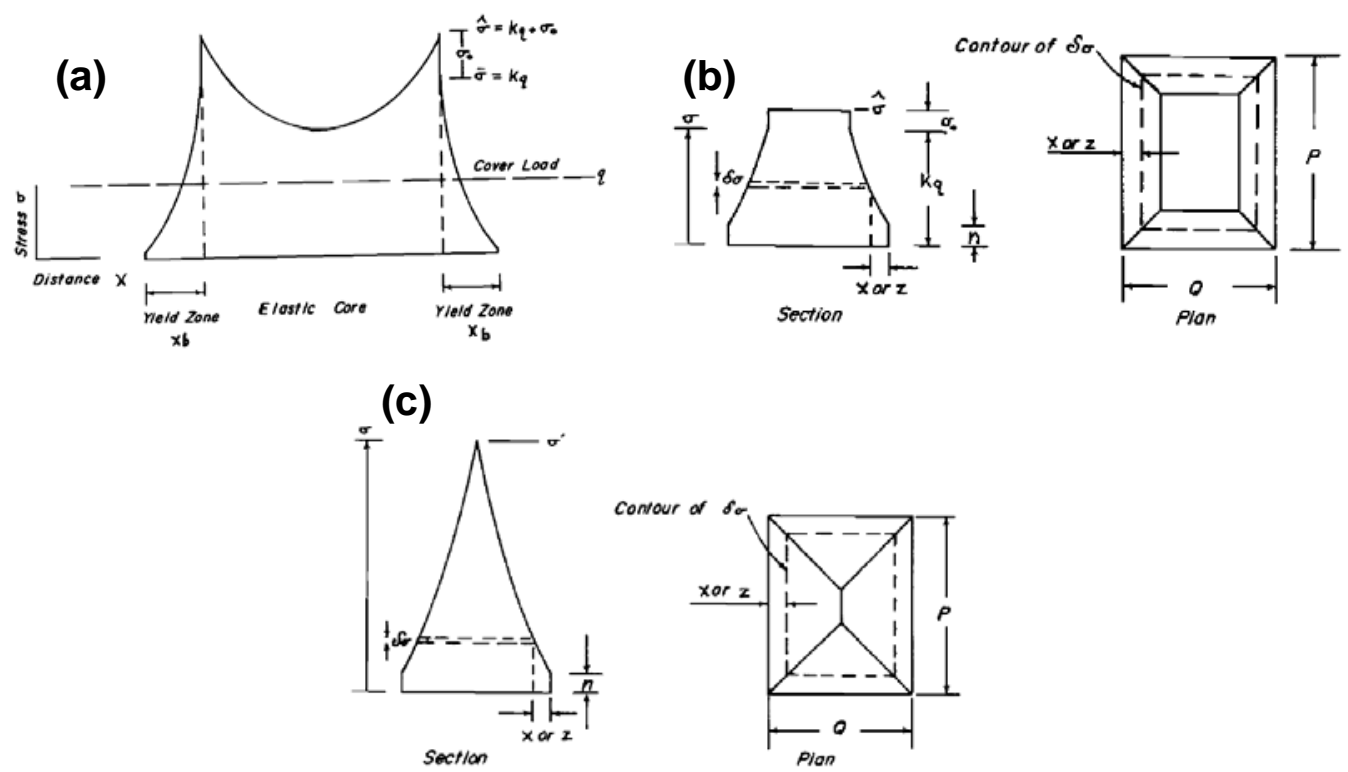

Figure 2.9 Vertical stress distribution (a) Wide pillars, (b) Limit of roadway stability, (c) Ultimate limit (after Wilson, 1982). 
Barron (1984) established an analytical method similar to the Wilson's method for calculating coal strength. He published the latest version of his method in the first coal pillar mechanics workshop (Barron and Pen, 1992). He implemented a nonlinear Hoek-Brown criterion for failure of intact pillar core and a linear Coulomb criterion for stress in the yield zones.

Salamon (1992) indicated that one of the drawback of the analytical models detailed above is: they did not consider the effect of the surrounding rock mass. Numerical methods such as Finite Element (Husing and Peng, 1984; Kripakov, 1981), Finite Difference (Esterhuizenet al., 2010; Gale, 1992, 2010) Boundary Element (Zipf, 1992; Heasley, 1998, 2010; Salamon, 1992) can include the effect of the surrounding strata in the solution. The strength of the coal pillar can be simulated by the mechanical properties of the coal (Husing and Peng, 1984) or by empirical coal pillar formulas (Heasley, et al., 2010) in the domain of the numerical solution. In addition, mechanical properties of the coal can be calibrated to mimic the empirical coal strength formulas during a numerical analysis (Esterhuizen et al., 2010).

\subsection{In-situ Stress Measurements}

Generally, in-situ stress measurements are performed to investigate the critical design parameters like abutment angle (Mark, 1992), abutment extent (Peng and Chiang, 1984) or pillar strength (Maleki, 1992). There are several different methods and devices to measure in-situ stress (Peng, 2008). The devices employed in the stress measurements collected for this dissertation are either: Vibrating Wire Stressmeters (VWS) or one of the hydraulic pressure cells, the Borehole Pressure Cells (BPC) or the Borehole Platened Flatjack (BPF). All of these stressmeters indicate the stress change after installation, not the total in-situ stress.

The VWS consists of a thin wire which is diametrically installed into a thick-walled steel cylinder (Figure 2.10). The wire is pre-tensioned and to take a measurement, the wire is vibrated by a coil and magnet. The vibration frequency of the wire is proportional to the square root of the wire tension which is related with the wire length. When the VWS is placed into a circular hole, the stress induced deformation of the wall of the borehole also deforms the VWS body. This deformation changes the wire tension and the natural frequency of the vibration. The stress change on the VWS can be determined from the change of the wire frequency. 


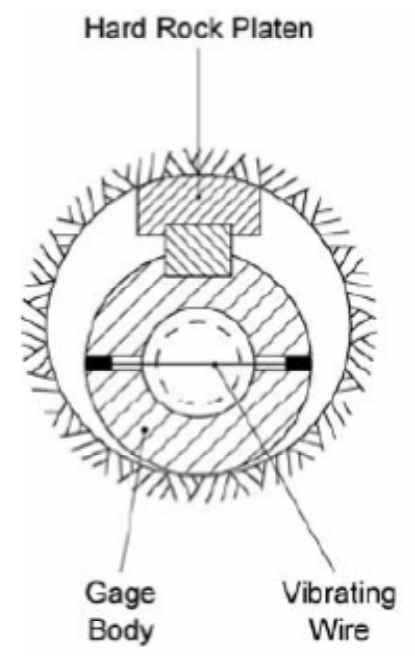

Cross Section

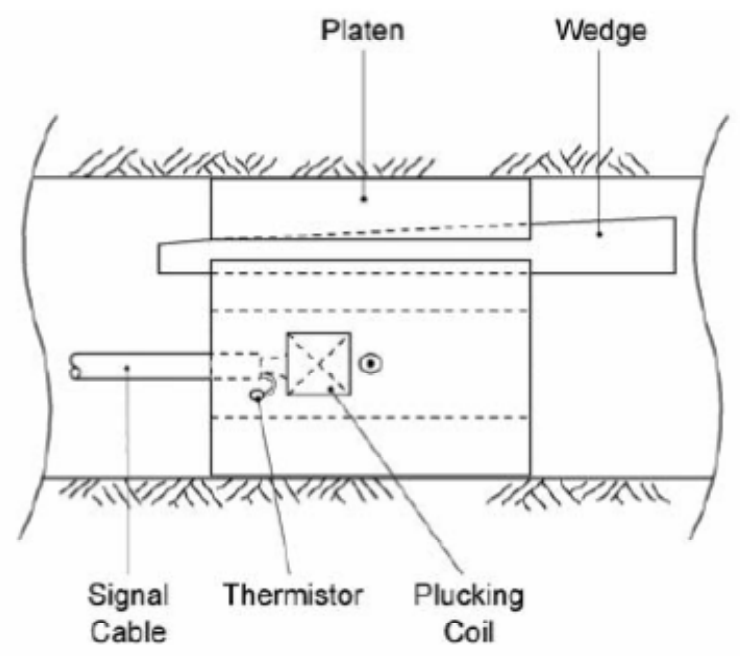

Side View

Figure 2.10 Vibrating Wire Stress (VWS) meter (after Geokon, 2004).

The components of the BPC are shown in Figure 2.11 (Babcock, 1980). In this figure, the steel bladder (A) is; encapsulated in a concrete cylinder (B), filled with hydraulic fluid, and connected to a pressure gage (D) through a length of tubing (C). The BPC is then pressurized inside of a circular borehole, and as the rock stress increases on the borehole, the fluid pressure inside the cell also proportionally increases. In order to convert the change of fluid pressure in the cell to the corresponding change of ground pressure, it is necessary to calibrate the response of the cell in the rock. The Borehole Platened Flatjack (BPF) is very similar to the BPC except that the steel bladder in the BPF is enclosed by steel platens as opposed to the encapsulating grout of the BPC (Heasley, 1989). Both the BPF and BPC can only measure unidirectional stress changes.

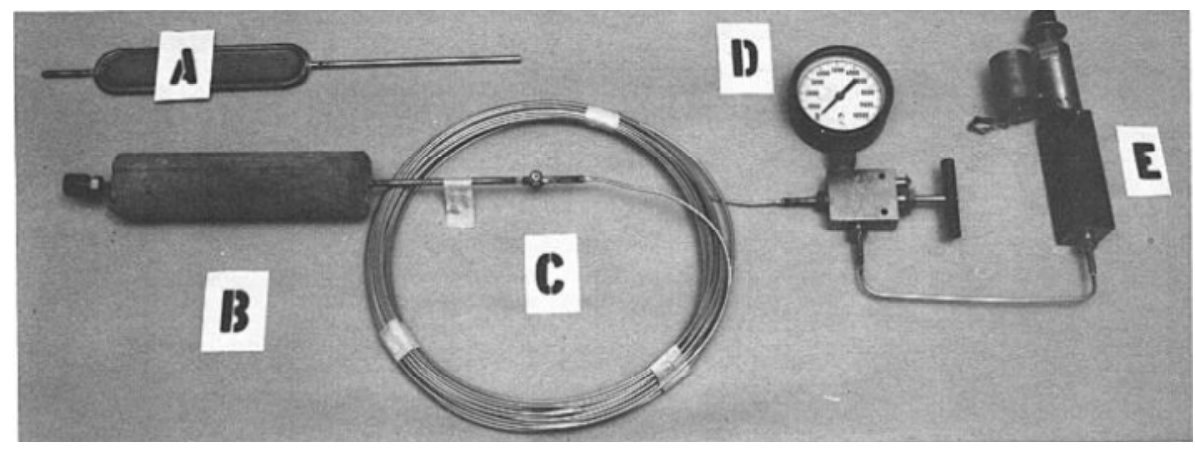

Figure 2.11 Borehole Pressure Cell (BPC) (after Babcock, 1980). 
Each of the VWS, BPC and BPF stressmeters have to be calibrated to determine rock stress, and the exact calibration of these instruments depends upon many factors including the host rock elastic constants, the pre-stress applied during installation, the orientation of the stressmeter with respect to the principal rock stress direction, the platen contact area, etc. (Peng, 2008; Babcock, 1980; Heasley, 1989; Lu, 1984; Su and Hasenfus, 1990). It is indicated in the manual (Geokon, 2004) prepared for the VWS that the accuracy of the gage reading is largely indeterminate, and that the indicated stress change magnitude can only be an approximate value and not an actual value. This statement is not only correct for the VWS, but is probably also true for the BPC and BPF.

\subsubsection{Field Measurements for Pillar Strength}

There are wide varieties of techniques for calculating coal pillar strengths. Mark and Iannacchione (1992) evaluated the most accepted pillar strength calculation methods by using a comprehensive data base of stress measurements from actual coal pillars. They used five empirical methods (Salamon and Munro, 1967; Holland and Gaddy, 1957; Bieniawski, 1981; Sheorey et. al, 1986; Obert-Duvall, 1967), three analytical methods (Wilson, 1982; Barron, 1984; Salamon and Wagner, 1985) and two numerical methods (Peng and Hsuing, 1984; Kripakov, 1981).

First, they adjusted the methods so that all the methods yielded the same strength prediction for a pillar width-to-height ratio of 5 . Then, they increased the pillar width and investigated the theoretical strength change predicted by each method. Mark and Iannacchione (1992) observed three general trends: 1) an exponential increase in pillar strength as pillar width was increased;2) a pillar strength that tended towards some maximum limiting value; 3) an approximately linear increase in strength as pillar width was increased.

After the theoretical comparison of the pillar strength methods, Mark and Iannacchione compared these methods with the actual stress measurements of 34 stress profiles from 6 different mines. Since stress measurements were made at discrete points, Mark and Iannacchione (1992) derived stress gradients for the empirical methods. The stress gradients were readily obtained for analytical and numerical methods.

The stress measurement database used by Mark and Iannacchione consisted of three types of measuring devices: VWS, BPC and BPF. The VWS data were reduced according to calibration 
procedures proposed by Hawkes and Bailey (1973) and adjusted using measured horizontal stress data. The BPF data were reduced according to calibration method proposed by Heasley (1989) and the BPC data were used as cell pressures. The stress measurement database used by Mark and Iannacchione (1992) is summarized in Table 2.1.

Table 2.1 Stress measurement database (Mark and Iannacchione, 1992)

\begin{tabular}{|c|c|c|c|}
\hline Name of the Mine & $\begin{array}{c}\text { Number of Stress } \\
\text { Profile Used }\end{array}$ & $\begin{array}{c}\text { Stress Measurement } \\
\text { Device }\end{array}$ & Location \\
\hline Kitt & 4 & VWS & Barbour County, WV \\
\hline Keystone No. 1 & 10 & VWS & $\begin{array}{c}\text { McDowell County, } \\
\text { WV }\end{array}$ \\
\hline VP No. 3 & 6 & BPF & Vansant, VA \\
\hline Foidel Creek & 8 & BPC & Oak Creek, CO \\
\hline Plateau & 4 & BPC & Price, UT \\
\hline Lynch No 37. & 2 & VWS & Harlan County, KY \\
\hline
\end{tabular}

$$
\begin{aligned}
& \text { VWS }=1360\left(0.8+0.2 \frac{w}{h}\right) \\
& B P F=1289\left(0.46+0.54 \frac{w}{h}\right) \\
& B P C=525\left(\frac{w}{h}-1\right)
\end{aligned}
$$

Mark and Iannacchione (1992) used a linear regression line to approximate the stress gradient data observed from the field measurements. They fitted a linear gradient stress function for the dataset of each device separately, and they derived one average stress gradient function for all of the datasets. Finally, they derived a pillar strength formula for each device to compare with the pillar strength calculation methods detailed above (Equation 2.12, 2.13, 2.14). These 
field measurement based strength formulas predicted a pillar strength higher than the calculation methods, but the stress increase rate observed was much lower than the calculation methods predicted (Figure 2.12).

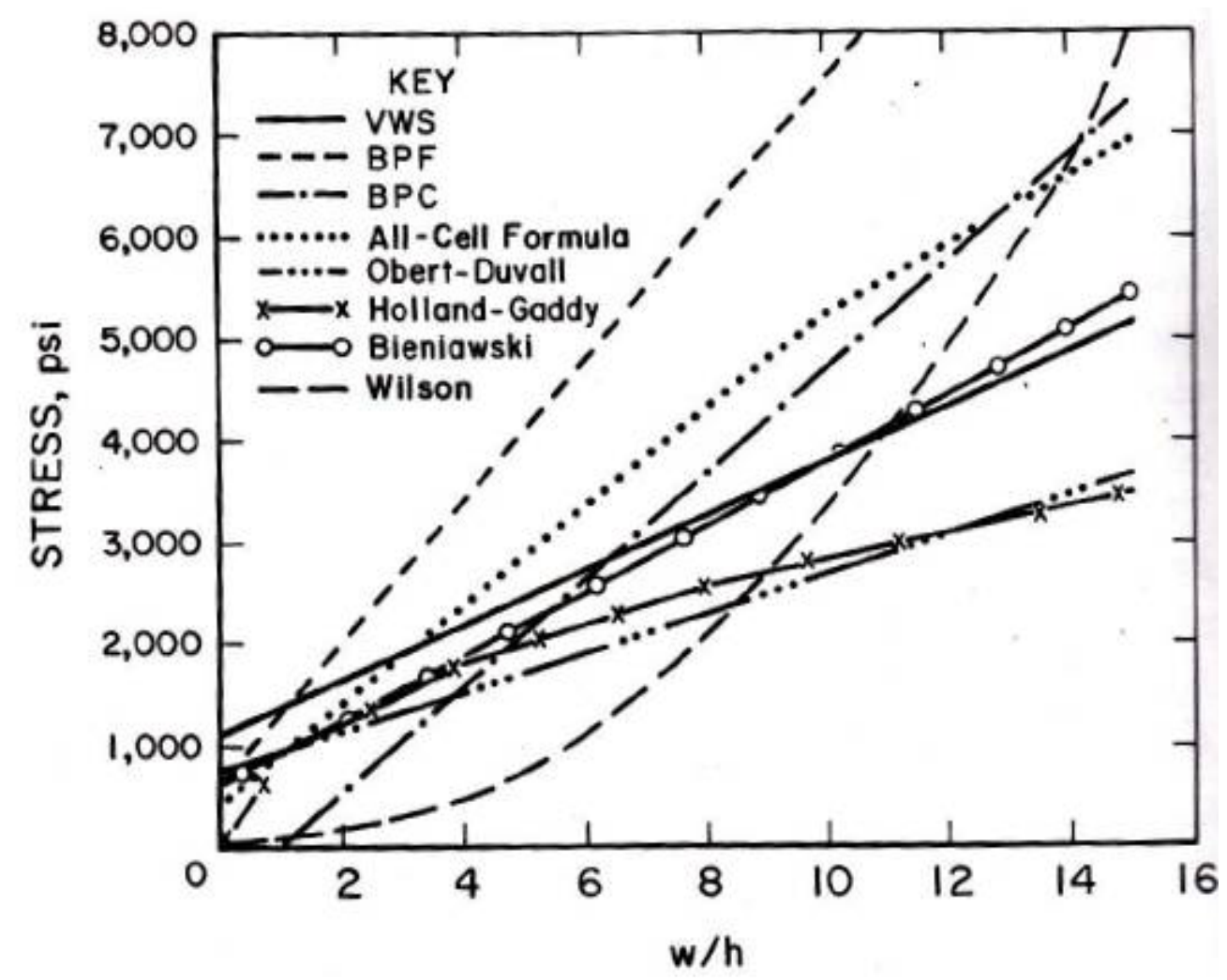

Figure 2.12 Pillar strength formulas obtained from stress measurements compared with existing formulas (after Mark and Iannacchione, 1992).

Maleki et al. (1987), based on in-situ pillar strength determination studies performed in three western coal mines, stated that existing pillar strength prediction methods were inadequate. In his studies, three headgate pillars in three Utah mines were instrumented with vertical, horizontal and cylindrical pressure cells, roof/floor convergence stations and rib extensometers. Development loads on the pillars were determined from overcoring stress analysis and finite element modeling. The pressure cells were calibrated as proposed by Babcock (1986) and used to determine stress changes due to retreat mining.

Maleki claimed that the strength of the pillars increased with increasing overburden depth due to a rise in pillar confinement. His study also showed that the roof and/or floor rock properties affected the pillar strength. For instance, the Blind Canyon coal pillar took very high load by resisting breakage. Maleki claimed that this pillar would have burst if the floor did not 
provide a cushion action. Significant floor heave observed on the gate road reduced the pillar confinement and prevented the pillar burst. Maleki stated that pillar strength might not only be depended on pillar shape as assumed by empirical formulas, but also on roof/floor and pillar frictional contact properties.

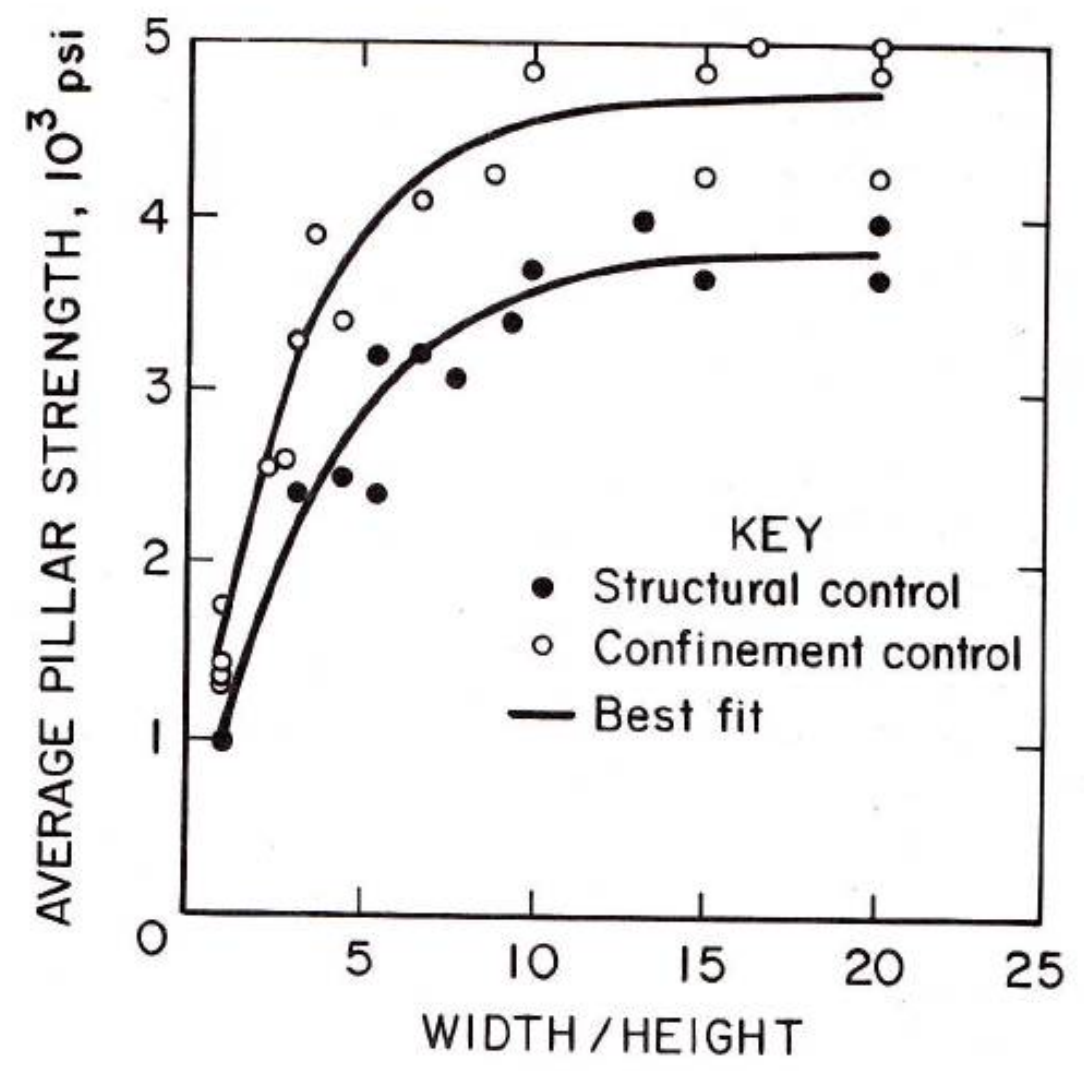

Figure 2.13 Best-fit curves for in-situ pillar strengths (after Maleki, 1992)

Maleki (1992) proposed a couple of in-situ pillar strength formulas based on his long-term observations, geotechnical monitoring and back analysis of the pillar failures in eight mines and seven coal seams. He grouped the in-situ pillar strength data into two categories (Figure 2.13): 1) structural control (low strength curve), 2) confinement control (high strength curve). Pillars in the confinement control group had high strength due to a large degree of confinement, and pillars in the structural control group had low strength due to the effect of cleats, in-seam bedding planes, weak contact planes and floor heave. The in-situ pillar strength formulas proposed by Maleki (1992) for the structural control group and the confinement control group are shown in Equations 2.15 and 2.16 .

$$
S_{p}=3836\left(1-e^{-0.260 \frac{w}{h}}\right)
$$




$$
\mathrm{S}_{\mathrm{p}}=4700\left(1-\mathrm{e}^{-0.339 \frac{\mathrm{w}}{\mathrm{h}}}\right)
$$

\subsubsection{Field Measurements for Abutment Loads}

Between 1970 and 1990, the former US Bureau of Mines (now NIOSH) had been engaged in investigations to determine in-situ ground control design parameters necessary to design safer longwall mines. Lu (1982) summarized one of the comprehensive site investigation performed in five US longwall mines from three states; 1) Deer Creek, Wilberg and Sunnyside mines in Utah, 2) York Canyon mine in New Mexico and 3) Federal No. 2 mine in West Virginia.

$\mathrm{Lu}$ indicated that in order to design a safe mine, realistic and precise values of the design parameters must be determined by measuring existing pressure, abutment loads, strata convergences and stiffness of the coal seam and overburden strata. Lu explained that existing pressures were measured by CPC and BPC cells, modulus of rigidity of rock and coal were measured by CPC, abutment loads were measured by BPC and roof/floor displacements were measured by convergence stations. $\mathrm{Lu}$ observed that front abutment pressure extended approximately 0.18 to 0.33 times the overburden depth and it reached a maximum when the face was 19 to $23 \mathrm{ft}$ away from the stress cells. He also said that the peak stress was observed at a distance of mining height (seam extraction thickness) and yield zone distance was equal to the mining height.

Haramy and Kneisley (1989) detailed the field measurements performed by the US Bureau of mine in two western longwall mines to investigate the stress distribution during the different mining stages under different overburden depths. Overburden depth over the instrumentation sites ranged from $450 \mathrm{ft}$ to $2000 \mathrm{ft}$. BPCs were used to measure the stress changes. They found that abutment pressure change was observed when the face was within 0.25 times the overburden depth, and a significant increase in the stress level was seen when the face was within 0.1 times the overburden depth. They indicated that peak stress was within 0.01 times the overburden depth inby the longwall face.

\subsubsection{Original Stress Measurements for Abutment Extent}

Peng (2008) indicated that over the last 30 years, considerable underground instrumentation on pressure changes around longwall panels had been performed. He states that the field studies performed prior to the mid-1980s measured front abutment, side abutment and gob load 
distributions. After the mid-1980s, the longwall panel widths grew wider and most of the subsequent stress measurements were designed to measure the side abutment load for gate road pillar design.

Peng and Chiang (1984) summarized the abutment stress measurement studies performed prior to the mid-1980s and they developed an equation for calculating the extent of the abutment load (D) as a function of the depth (H) (in $\mathrm{ft})$.

$$
\mathrm{D}=9.3 \sqrt{\mathrm{H}}
$$

Equation 2.17 was derived from 8 sets of stress measurement collected from 6 different mines. The depths at the 8 stress measurement sites ranged from $450 \mathrm{ft}$ to $875 \mathrm{ft}$ with an average of $585 \mathrm{ft}$. The extraction thicknesses at the case study sites went from a low of $4.00 \mathrm{ft}$ to a high of $7.50 \mathrm{ft}$ with an average of $5.61 \mathrm{ft}$. The panel widths ranged from $150 \mathrm{ft}$ to $490 \mathrm{ft}$ with an average of $321 \mathrm{ft}$. Table 2.2 summarizes the panel geometric parameters from the 8 stress measurement sites used by Peng and Chiang (1984) to develop Equation 2.17.

Table 2.2 Summary of the stress measurements used by Peng and Chiang (1984).

\begin{tabular}{|c|c|c|c|c|c|}
\hline & \multicolumn{5}{|c|}{ Panel Dimensions } \\
\hline Mine & $\begin{array}{c}\text { Mining } \\
\text { Height } \\
\text { (ft) }\end{array}$ & $\begin{array}{c}\text { Panel } \\
\text { Depth } \\
\text { (ft) }\end{array}$ & $\begin{array}{c}\text { Panel } \\
\text { Width } \\
\text { (ft) }\end{array}$ & $\begin{array}{c}\text { Panel } \\
\text { Length } \\
\text { (ft) }\end{array}$ & Seam Name \\
\hline Valley Camp No.3 & 5.25 & 875 & 150 & 2655 & Pittsburgh \\
\hline Hendrix No. 22 & 5 & 450 & 150 & 2000 & Elkhorn \#3 \\
\hline Old Ben No. 24 & 7.5 & 620 & 462 & 1735 & Herrin \#6 \\
\hline Olga No.1 & 4 & 630 & 360 & 4200 & Pocahontas \#4 \\
\hline Quarto No. 4 & 6.5 & 500 & - & - & Pittsburgh \\
\hline Capco & 6 & 570 & 484 & 3100 & Pittsburgh \\
\hline
\end{tabular}




\subsubsection{Original Stress Measurements for Abutment Angle}

In 1992, Mark (1992) also analyzed the abutment stress measurements from five U.S. mines, but in this case to infer the magnitude of the abutment loads and associated abutment angle. In this study, VWSs were used for all of the field studies. Mark $(1992,1987)$ calculated the measured side abutment load by multiplying the load-bearing area of the pillars by the average pillar stresses determined from the array of stress cells inside each pillar. In these studies, there were not any stressmeters installed inside the solid coal of the next panel; therefore, during the calculation of the measured side abutment loads, the load on the adjacent solid coal was ignored. A summary of the panel depths from the cases that were used by Mark (1992) to back calculate abutment angles is shown in Table 2.3. Mark concluded that an average abutment angle value of $21^{\circ}$ would yield a conservative estimate of the side abutment load, but there was a standard deviation of $4.9^{\circ}$ in the measured values as seen below.

Table 2.3 Summary of the stress measurements used by Mark (1992).

\begin{tabular}{|c|c|c|c|c|}
\hline Case & $\begin{array}{c}\text { Panel Depth } \\
\text { (ft) }\end{array}$ & $\begin{array}{c}\text { Panel Width } \\
\text { (ft) }\end{array}$ & Seam & $\begin{array}{c}\text { Abutment Angle } \\
\text { (deg.) }\end{array}$ \\
\hline Mine A: 2 & 520 & 470 & Pittsburgh & 21.8 \\
\hline Mine B: 2 & 650 & 600 & Pittsburgh & 25.2 \\
\hline Mine B: 3 & 600 & 600 & Pittsburgh & 10.7 \\
\hline Mine B: 4 & 455 & 600 & Pittsburgh & 17.3 \\
\hline Mine D: 1 & 760 & 1000 & $\begin{array}{c}\text { Lower } \\
\text { Kittanning }\end{array}$ & 18.5 \\
\hline Mine E: 3 & 630 & 500 & Harlan & 20.3 \\
\cline { 4 - 5 } & & & Average & 18.97 \\
\cline { 4 - 5 } & & &
\end{tabular}

From the stress measurements at the five mines, Mark derived a function for the abutment stress distribution that had a square decay with distance from the edge of the panel (Equation 2.18). He used the front abutment data set because it had the enough data point to derive this equation. Mark (1992) used a normalized average pillar stress and a normalized pillar location graph shown in Figure 2.14 to derive Equation 2.19 to calculate the fraction $\mathrm{R}$ of the total side abutment load carried by the chain pillars. 


$$
\begin{aligned}
& \sigma_{\mathrm{a}}(\mathrm{x})=\frac{3 \mathrm{~L}_{\mathrm{s}}}{\mathrm{D}^{3}}(\mathrm{D}-\mathrm{x})^{2} \\
& \mathrm{R}=1-\left[\frac{\mathrm{D}-\mathrm{x}}{\mathrm{D}}\right]^{3}
\end{aligned}
$$

where:

$$
\begin{aligned}
& \sigma_{\mathrm{a}}=\text { the abutment stress level. } \\
& \mathrm{x}=\text { the distance from the panel edge. } \\
& \mathrm{L}_{\mathrm{s}}=\text { the total side abutment load. } \\
& \mathrm{D}=\text { the extent of the abutment stress. }
\end{aligned}
$$

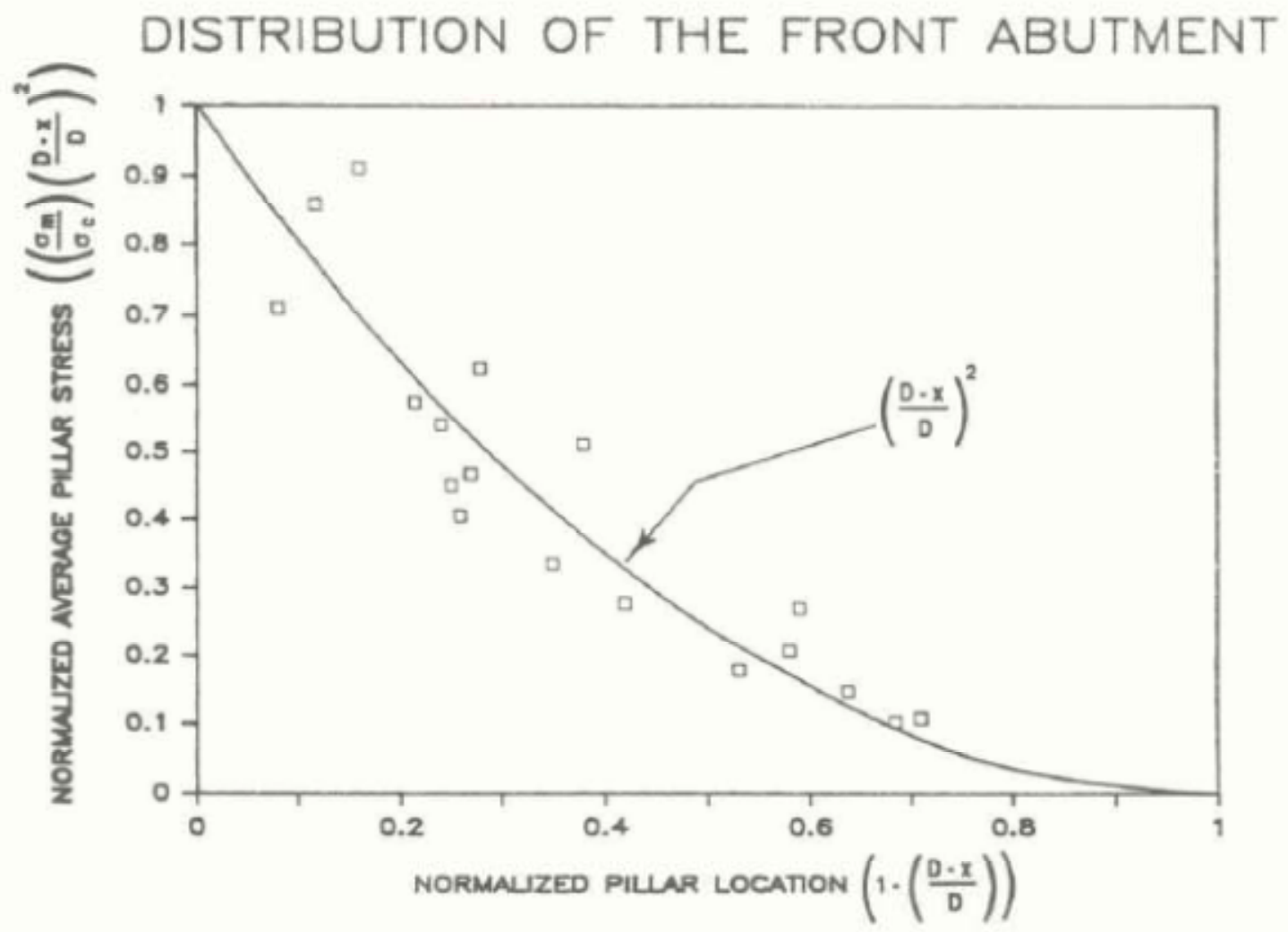

Figure 2.14 Stress decay with distance (after Mark, 1992).

More recently, analyses of stress measurements performed in six Australian mines showed that the abutment angle might be considerably less than the $21^{\circ}$ under deep cover (Colwell et al., 1999). During the analysis of these Australian stress measurements, Colwell et al. (1999) used the same approach as Mark. 


\subsubsection{Stressmeter Variability}

As discussed above, using 36 different pillar stress profiles measured in six different mines, Mark and Iannacchione (1992) derived individual pillar strength formulas for each of the stress measuring devices: VWS (Equation 2.12), BPC (Equation 2.13) and BPF (Equation 2.14), as a function of pillar width (w) and pillar height (h). They indicated that the stress measurements displayed considerable variability because of different cell types and calibration procedures. They identified the development of better calibration procedures for stress cells as a critical research area.

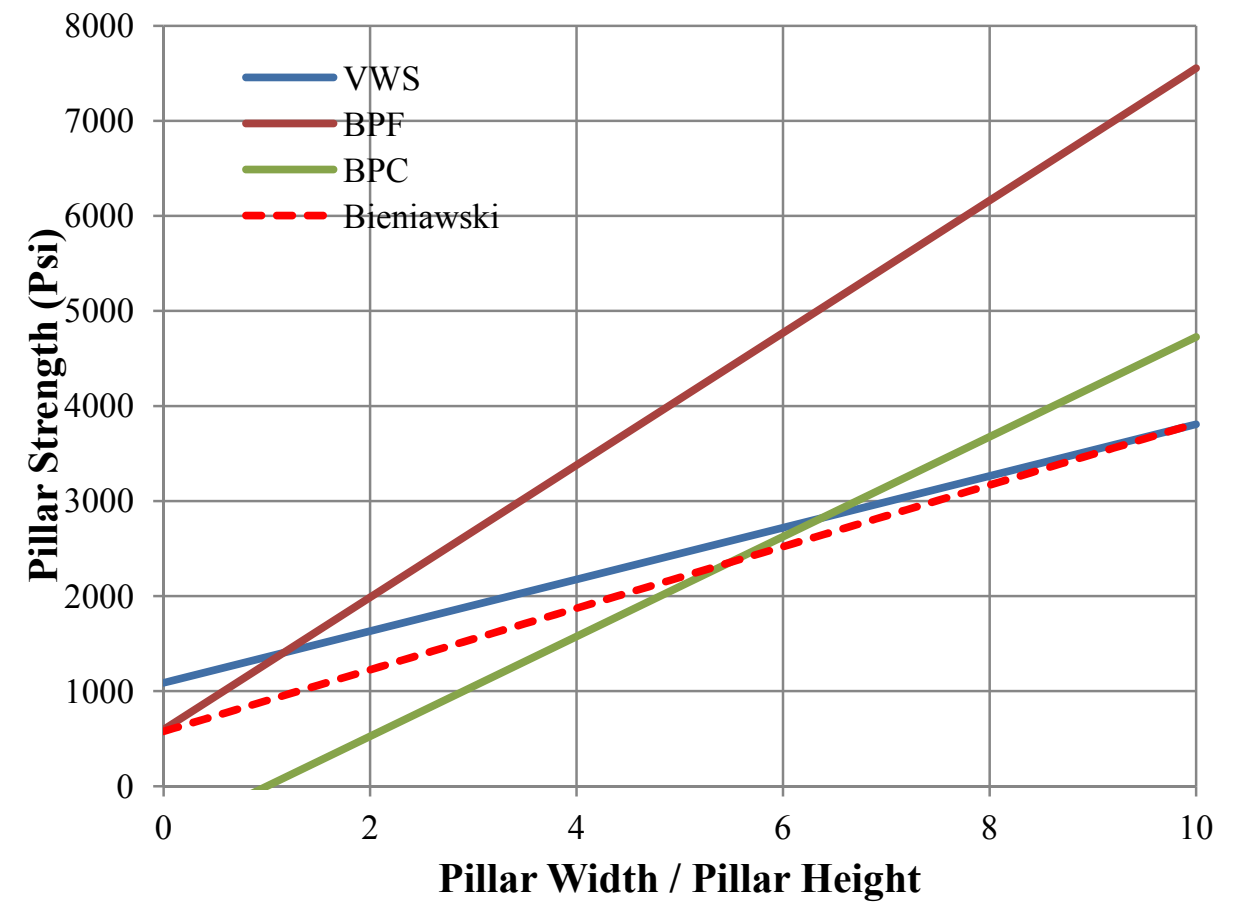

Figure 2.15 In-situ stress measurements and Bieniawski formula.

Figure 2.15 shows a comparison of the pillar strength formulas derived from the different stressmeters and the Bieniawski pillar strength formula. In this figure, the VWS, BPC and Bieniawski formulas match fairly well, but the BPF cell shows distinctly higher strength. Higher strength shown by BPF cells is not due to the strong pillar, rather it is due to the stiff response of the BPF cell.

The main conclusion that should be derived from Figure 2.15 is that the stress change values measured by the different stress cells might not give directly comparable in-situ stress changes. As indicated in the Geokon manual (2004), the measured stress changes are only an approximation. This is the reason that Mark $(1987,1992)$ used only VWS cells and the same 
calibration procedure in the five case studies to derive the $21^{\circ}$ abutment angle; therefore, all measurements were consistent in his analysis.

\subsection{The ARMPS Program}

Researchers from NIOSH developed the original ARMPS program in the mid 1990's (Mark and Chase, 1997). The original program uses the tributary area method to estimate the development loads on the "Active Mining Zone" (AMZ), and the "abutment angle" concept is used to estimate the loads transferred to the pillars during pillar extraction (see Figure 2.7). Mark and Chase (1997) defined the AMZ as the distance from the active face where $90 \%$ of the abutment loads fall (Mark, 1992). This distance is calculated with an empirical Equation 2.20 which was derived from the analysis of the field measurements (Mark, 1992). The program then calculates the strength of the pillars using the Mark-Bieniawski formula. Ultimately, the "Stability Factor" (SF) of the AMZ is calculated by dividing the load bearing capacity of the AMZ by the total estimated load applied to the AMZ (Mark, 2009). The loading assumptions used in the ARMPS program mirror those from the Analysis of Longwall Pillar Stability (ALPS) program which was previously developed for longwall pillar design (Mark, 1992).

$$
\mathrm{D}_{0.9}=5 \sqrt{\mathrm{H}}
$$

Mark $(2009,2010)$ states that the strength of the ARMPS program does not come from the accuracy of its load calculations rather, its strength comes from the large database for which ARMPS is calibrated. The original version of ARMPS (Mark and Chase, 1997) was calibrated with a data base of 150 cases, and a stability factor of 1.5 was suggested when designing retreat panel pillars. However, it was soon found that the ARMPS SF became less meaningful when the depth of cover exceeded $750 \mathrm{ft}$ and that there was a need of further research on pillar design for retreat mining under deep cover (Chase et al., 2002).

In 1997, NIOSH investigators initiated new research on deep cover pillar retreat by specifically collecting new data from deep cover mines. The goal of this research was to develop appropriate criteria for applying ARMPS to design pillars for deep cover pillar retreat panels (Chase et al., 2002). The result of this deep cover initiative was the ARMPS 2002 version of the software which was developed from 250 case histories. According to the ARMPS 2002 guidelines, a stability factor of 1.5 is satisfactory for the pillar retreat cases where the depth of 
cover is less than $650 \mathrm{ft}$. Between a depth of $650 \mathrm{ft}$ and $1250 \mathrm{ft}$, there is a linearly decreasing trend in the stability factor, and below a depth of $1250 \mathrm{ft}$, a SF of 0.9 (0.8 for strong roof) is recommended (see Figure 2.16, Table 2.4).

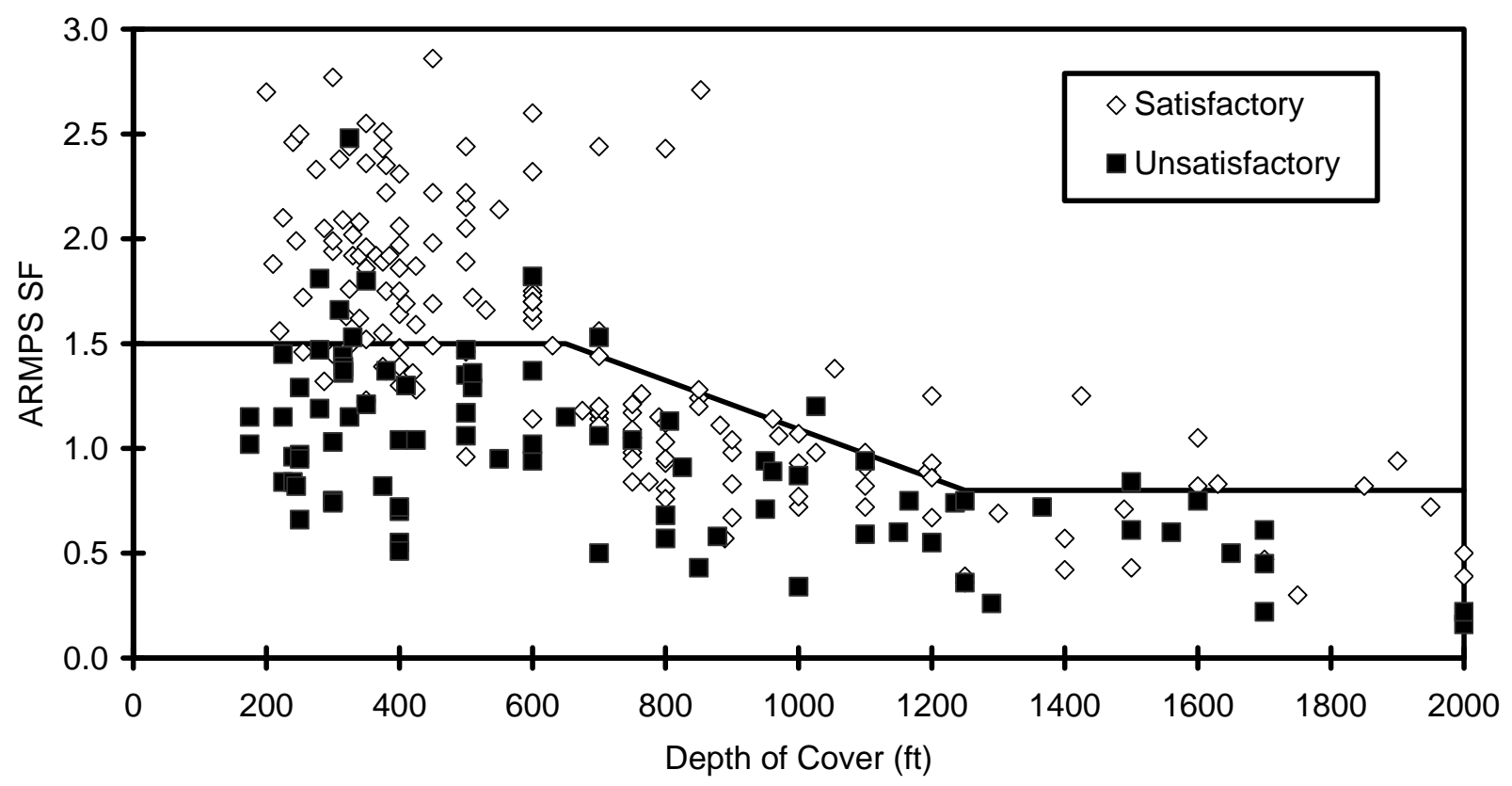

Figure 2.16 Recommended ARMPS SF from the 2002 deep cover study (after Chase et al., 2002).

Table 2.4 Recommended ARMPS stability factors (after Chase et al., 2002).

\begin{tabular}{|c|c|c|c|}
\hline & Depth $(\mathrm{H})$ & $\begin{array}{c}\text { Weak and } \\
\text { Intermediate } \\
\text { Strength Roof } \\
\end{array}$ & Strong Roof \\
\hline \multirow{3}{*}{ ARMPS SF } & $\mathrm{H}<650 \mathrm{ft}$ & 1.5 & 1.5 \\
\hline & $650 \mathrm{ft} \leq \mathrm{H} \leq 1,250 \mathrm{ft}$ & $1.5-[\mathrm{H}-650] / 1000$ & $\begin{array}{c}1.4-[\mathrm{H}-650] / \\
1000\end{array}$ \\
\hline & $\begin{array}{c}1,250 \mathrm{ft} \leq \mathrm{H} \leq 2,000 \\
\mathrm{ft}\end{array}$ & 0.9 & 0.8 \\
\hline \multirow{2}{*}{$\begin{array}{r}\text { Barrier Pillar } \\
\text { SF }\end{array}$} & $\mathrm{H}>1,000 \mathrm{ft}$ & $\geq 2.0$ & $\geq 1.5^{*}(\geq 2.0 * *)$ \\
\hline & $\mathrm{H}<1,000 \mathrm{ft}$ & \multicolumn{2}{|c|}{ No Recommendation } \\
\hline
\end{tabular}

*Non-burst-prone ground

***Brst-prone ground

A significant outcome of this deep cover research was the realization of the significance of sufficiently strong barrier pillars. Out of 57 deep cover case histories, only one failure occurred when the SF was $\geq 0.8$ and the barrier pillar stability factor was $\geq 2.0$. Conversely, out of 30 of 
the case histories that had a SF $<0.8$ and a barrier pillar $\mathrm{SF}<2.0,60 \%$ were failures. This research did show that lower stability factors may be successful with deeper cover. Two possible explanations for this result were discussed: 1) the actual strength of the large pillars at depth might be higher than predicted by the Mark-Bieniawski formula, or 2) the pillar loads as predicted by ARMPS are higher than the actual pillar loads.

It seemed most reasonable that ARMPS was over estimating the actual pillar loads. Heasley (2000) indicated that pillar loading was as important as pillar strength in panel design and there has not been enough research in this area. In his paper, he questioned the accuracy of the empirical abutment angle concept under deep cover by using elastic and laminated overburden models and concluded that ARMPS possibly over predicts the abutment load in the deep cover cases. Similar results were observed by Colwell et al. (1999) where they back calculated the abutment angle from the field measurements collected from Australian coal mines. In these measurements, they found that the abutment loading, and therefore the abutment angle of the deep mines, was considerably less than the default $21^{\circ}$ abutment angle used in ARMPS (Figure 2.17).

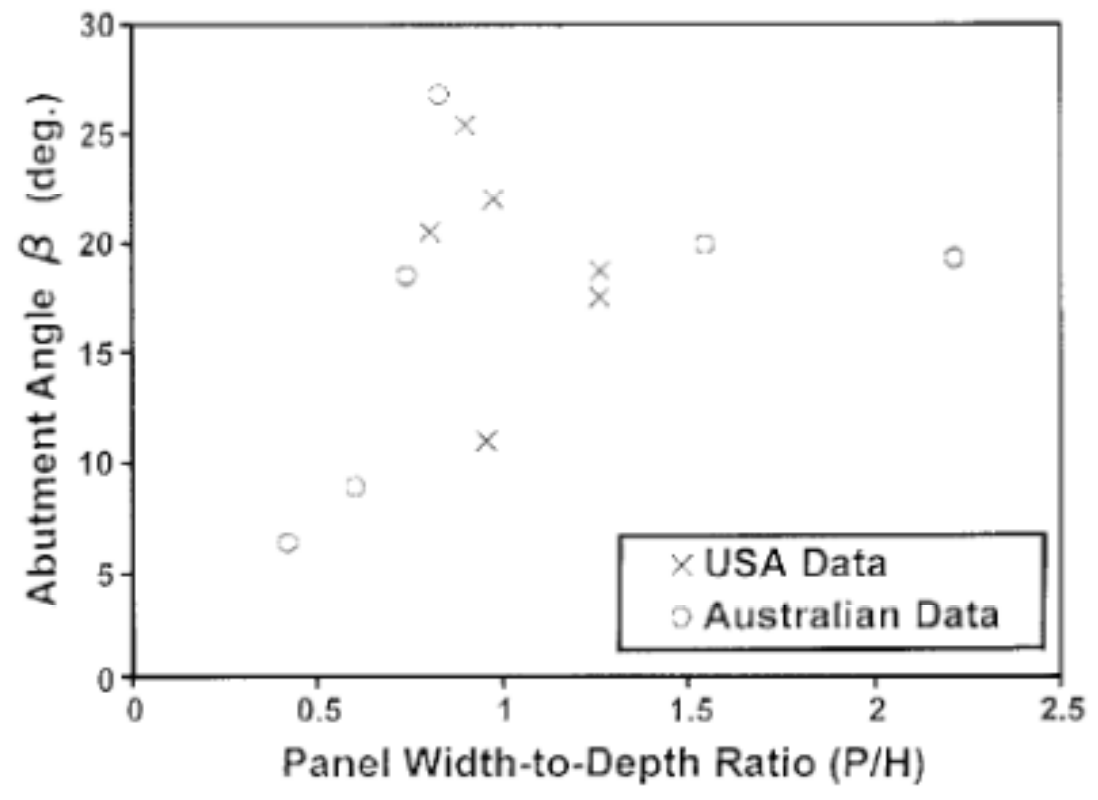

Figure 2.17 Abutment angles back calculated from Australian mines (after Collwel et al., 1999).

After the Crandall Canyon disaster, Mark (2010) re-analyzed the deep-cover pillar retreat analysis with ARMPS and implemented a "pressure arch" concept. The new version of ARMPS which implements the pressure arch loading is called ARMPS 2010. The new overburden 
loading algorithm takes the tributary area loading on the active mining zone (AMZ) and reduces it by the pressure arch factor (see, Equation 2.2). The extra AMZ loads are then transferred to the adjacent barrier pillars. If the barrier pillars are too small to carry all of the applied loads, then the pressure arch loads are transferred back to the AMZ. With the addition of this new loading algorithm, the previous depth effect seen in ARMPS 2002 was eliminated (see Figure 2.18).

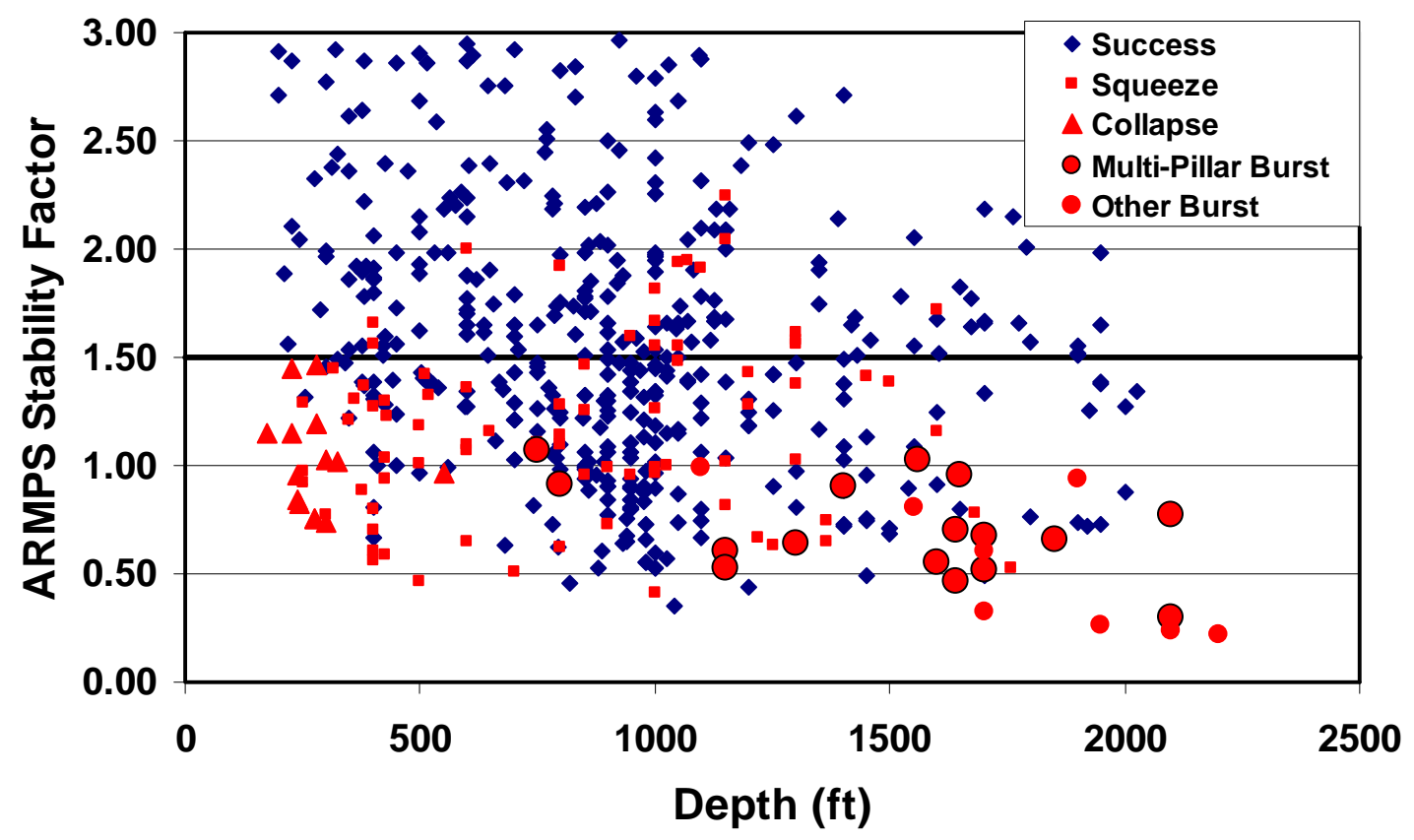

Figure 2.18 Recommended ARMPS SF from the 2010 deep cover study (after Mark, 2010).

\subsection{LaModel and Calibration for Deep Cover Mining}

Numerical models are also commonly used to help in pillar design, and in the U.S. coal industry, the LaModel program is frequently the chosen model. The LaModel program was originally developed in 1993. It is a boundary element program that simulates a laminated overburden as a stack of frictionless plates (Heasley, 1998). Within the seam, the different coal and gob areas are represented by elements with various stress-strain behaviors. Using the stiffness behavior of the seam elements and the prescribed flexure of the overburden, the LaModel program can calculate the displacements and loads throughout the modeled area of the seam.

The LaModel program uses the displacement-discontinuity (DD) variation of the boundaryelement method. In the displacement-discontinuity (DD) approach, mining horizon is treated 
mathematically as a discontinuity in the displacement of the surrounding infinite media. In this approach only the plan view of the seam is discretized and the distribution of stresses and convergences on the seam horizon are of interest. The computational efficiency of the DD analysis is very high compared to the other methods like finite element and finite difference which discretize all of the body. Because of the DD formulation, LaModel is able to analyze large areas of single or multiple-seam coal mines very efficiently (Heasley, 1998).

\subsubsection{Calibrating the LaModel Program for Deep Cover Pillar Retreat Coal Mining}

The accuracy of numerical analysis (in regard to pillar design) depends on the suitability of the numerical method and the appropriateness of the input parameters. Simply using mechanical material properties gathered from laboratory tests of rock samples is typically not sufficient to produce realistic, or accurate, rock mass models. Calibration of the model input parameters with respect to reality is typically needed.

Recently, a calibration method has been developed for the LaModel program which essentially attempts to duplicate the abutment loading, gob loading and pillar strength used in ARMPS (Heasley et al., 2010). Essentially, the calibration method:

- adjusts the overburden stiffness in LaModel to match the abutment extent used in ARMPS,

- adjusts the gob modulus to match the magnitude of the gob/abutment loading (in two dimensions) as determined by the abutment angle concept used in ARMPS, and

- adjusts the coal properties to produces pillars with a Mark-Bieniawski strength as used in ARMPS.

\subsubsection{The Verification of the Deep Cover Retreat Mining Calibration Method}

In order to verify the recommended calibration method for LaModel, a database of deep cover retreat mining case studies was developed (Heasley et al., 2010). For each of the case studies in the database, the LaModel mine grid was built directly from the mine map, and the true topography from the mine map was gridded into the LaModel overburden grid. The critical input parameters, as discussed above, were calibrated exactly as recommended. The safety factors for the detailed case study analysis were calculated by using the average stress-based pillar safety factor for the area within the Active Mining Zone (AMZ) as defined by ARMPS (Mark and Chase, 1997). 
The results of the database analysis using the recommended calibration method are shown in Figure 2.19. The area where the successful and failed designs overlap goes from a safety factor of 0.86 to a safety factor of 1.50 . This area encompasses a safety factor deviation of $\pm 0.24 \%$ and compares very well with an ARMPS analysis of the case studies which has an area that encompasses 41\% (Heasley et al., 2010). In the calibration analysis, only 4 failures out of 19 total occurred with an idealized safety factor above the recommended design line at 1.40 and only 1 success occurred with an idealized safety factor below 1.00. Therefore, if a safety factor of 1.40 is used as a design objective, there would be only an $8.5 \%$ (4 out of 47) chance of misclassifying a potential failure as a successful design.

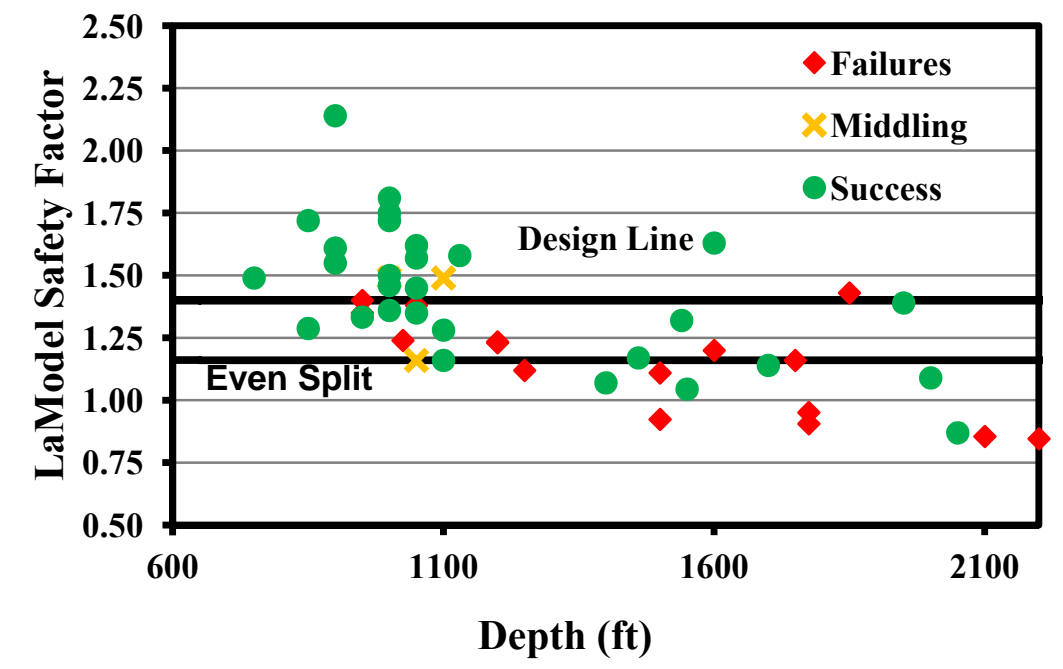

Figure 2.19 The LaModel safety factors for the calibration verification case histories (after Heasley et al, 2010).

\subsection{Summary and Discussions}

The design of a pillar for a mining operation consists of three basic steps: estimation of the loads applied to the pillar, estimation of the strength of the pillar and determination of the stability factor. For longwall and retreat room-and-pillar mines, it is necessary to determine the magnitude of both the development and the abutment loads. For calculating development loads several different methods have been proposed: the tributary area method (Mark, 1992), the pressure arch method (Mark, 2010) analytical methods (Kramer, 1996) and numerical methods (Heasley et al., 2010). However, regardless of the method used for calculating development loads, the abutment loads are generally determined using the abutment angle concept (Mark, 1992, 2010; Kramer, 1996; Heasley et al., 2010). 
In the U.S. underground coal industry, ALPS, ARMPS and LaModel programs have been used to design pillars. All three of these programs use an average $21^{\circ}$ abutment angle to calculate the magnitude of the total abutment load and the extent of the abutment loading is determined as solely a function of depth from an empirically derived equation (Equation 2.17). The average $21^{\circ}$ abutment angle abutment angle and empirical abutment extent equation (Equation 2.17) were derived from the back analysis of insitu stress measurements taken in the 70s and 80s (Mark, 1992; Peng and Chiang, 1984).

The new insitu stress measurement studies detailed in this chapter highlighted some important facts. First, current mines have significantly different panel dimensions than the mines where stress measurements were collected and used to derive the original empirical abutment extent formula (Equation 2.17, Equation 2.18). It can be seen from Table 2.3 that there were not any stress measurements from a panel deeper than $760 \mathrm{ft}$, and most panels were $600 \mathrm{ft}$ wide or less when the average $21^{\circ}$ abutment angle was determined. Front abutment extents observed from some of the Western U.S. mines (Haramy and Kneisley, 1989; Lu, 1982) showed a longer extent than the abutment extent predicted by Equation 2.17 (Table 2.5). Goodrich et al. (1999) also indicated that in the Deer Creek Mine in Utah under $2000 \mathrm{ft}$ depth of cover, an abutment extent distance of greater than $750 \mathrm{ft}$ was observed. This distance was considerably higher than the one predicted by the empirical abutment extent formula (Equation 2.17). Even though panel widths and depths have increased significantly since the 70s and 80s, in recent years, there has not been any updated or better approach proposed to predict abutment extent or abutment angle.

Table 2.5 Abutment extent observed in Western U.S. mines (Haramy et al., 1989; Lu, 1982).

\begin{tabular}{|c|c|c|}
\hline $\begin{array}{c}\text { Overburden Depth } \\
\text { (ft) }\end{array}$ & $\begin{array}{c}\text { Observed Front Abutment } \\
\text { Extent } \\
\text { (ft) }\end{array}$ & $\begin{array}{c}\text { Calculated Abutment Extent } \\
\text { (with Equation 2.17) } \\
\text { (ft) }\end{array}$ \\
\hline 2000 & 500 & 416 \\
\hline 1500 & 900 & 360 \\
\hline 750 & 188 & 255 \\
\hline 450 & 113 & 197 \\
\hline 1450 & 479 & 354 \\
\hline 919 & 165 & 282 \\
\hline 459 & 106 & 199 \\
\hline
\end{tabular}




\section{Chapter 3 Re-Analysis of Abutment Load}

\subsection{Introduction}

The field stress measurement studies used to derive the default $21^{\circ}$ abutment angle (Table 2.3) and the empirical abutment extent formula (Table 2.2 and Equation 2.17) detailed in the Chapter 2 highlighted some important problems. Current mines have significantly different panel dimensions than the mines where these previous stress measurements were collected and used to derive the original empirical abutment formulas. However, in the intervening years, there has not been any updated or better approach proposed to predict the abutment extent or the abutment angle. In this dissertation, these traditional values for abutment extent and abutment loading are re-examined using more recent in-situ stress measurements.

\subsection{Stress Measurement Database}

As part of this research to better define the abutment extent and the abutment angle, a database of stress measurements case histories was developed. In the database, there are six stress measurement case histories where multiple stress changes were monitored during the panel retreat (Table A.1). There are another six case histories where only the final full side-abutment stress change profiles were provided (Table A.2). In addition, there are 18 supplementary cases where only the total side abutment load was known and not the exact profile (Table A.3). Twenty two of the 30 case histories come from Australian longwall mines and the remaining 8 cases are from U.S. longwall mines. Table 3.1 shows the summary statistics for the 30 case histories used in this study.

Table 3.1 Summary statistics of the present stress measurement database.

\begin{tabular}{|c|c|c|c|c|}
\hline & $\begin{array}{c}\text { Panel Depth } \\
\text { (ft) }\end{array}$ & $\begin{array}{c}\text { Panel Width } \\
(\mathbf{f t})\end{array}$ & Depth / Width & $\begin{array}{c}\text { Mining Height } \\
\text { (ft) }\end{array}$ \\
\hline Average & 941 & 641 & 1.56 & 9 \\
\hline Standard Deviation & 495 & 148 & 0.91 & 3 \\
\hline Minimum & 410 & 344 & 0.45 & 5 \\
\hline Maximum & 2050 & 1000 & 3.43 & 12 \\
\hline
\end{tabular}




\subsection{Calibration of Stress Cells}

In analyzing the stress cell pressures, it is not necessarily important which stress cell calibration method is used as long as the method is consistent from site to site (Mark, 1992; Colwell et al., 1999). The stress measurement cases used in this research include three types of stress cells; vibrating wire stress cells (VWS), Hydraulic Stress Cells (HSCs) used in Australia and Borehole Platened Flatjacks (BPFs) used in the U.S. Each type of cell was calibrated according to the most accepted calibration procedure recommended for that device to try and calculate a true stress change in the coal pillar. However, it is known that the different types of cells with the recommended calibration techniques show different responses.

Using 36 different pillar stress profiles measured in 6 different mines, Mark and Iannacchione (1992) derived individual pillar strength formulas for each of the stress measuring devices (VWS, Borehole Pressure Cells (BPCs) and BPFs) as a function of pillar width (w) and pillar height $(\mathrm{h})$. Figure 2.15 shows a comparison of the pillar strength formulas derived from the different stressmeters and the Bieniawski pillar strength formula. In this figure, note that the VWS and Bieniawski formulas match fairly well and that the BPF cells show distinctly higher stress/strength.

In order to investigate the effect of stressmeter calibration technique during the analysis of the stress measurements presented in this paper, the stress cells at each site were identically calibrated by using an expected Bieniawski pillar stress gradient. To do this calibration, the stress cells which yielded at the pillar edge were first determined from the loading history of the cells and the stress profiles. For instance, Figure 3.1 shows the loading history of the stress cells from one case study. In this figure, some of the stress cells (4, 5, 6 and 7) measured a peak cell pressure change and then the cell pressure decreased. It is assumed that this behavior indicates that the coal around the cell has reached peak stress and then the coal has started to yield. After the cells within the yield zones were determined, the initial development load was estimated using tributary area loading. The estimated development load was added to the maximum stress change measured at the cell location to calculate the peak coal strength measured by the cell. Next, the expected Bieniawski pillar stress at the cell location was calculated from the stress gradient function (Equation 3.1) derived by Mark (1992).

$$
\sigma_{\mathrm{v}}(\mathrm{x})=6.2 \times\left(0.64+2.16 \frac{\mathrm{x}}{\mathrm{h}}\right)
$$


where:

$\sigma_{\mathrm{v}}=$ the coal strength.

$\mathrm{X}=$ distance from pillar rib.

$\mathrm{h}=$ height of pillar.

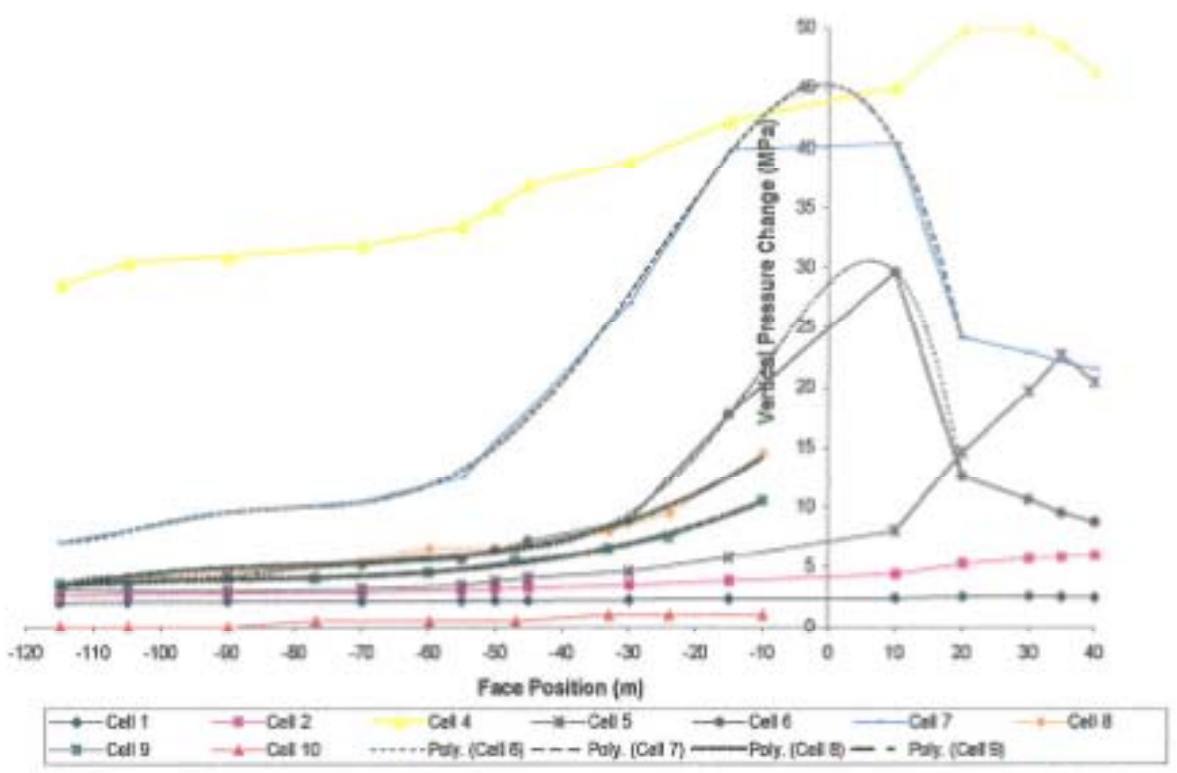

Figure 3.1 Loading history of the stress cells (after Colwell et al., 1999).

Then the expected coal strength versus the measured coal strength ratio at the cell location was calculated for each cell in the yield zone, and the average ratio of the all of the yielding cells was calculated. This average stress ratio was then used to adjust the measured stresses for all of the cells in that pillar.

\subsubsection{Comparison of the Calibration Methods}

In order to investigate the various stress meter calibration methods, six Australian stress measurement cases were used to compare the stress reduction factors used in Australia to calibrate HSC stress cells with the stress reduction factors derived according to expected Bieniawski stress gradient as described above.

The HSC cells were developed by Mincad Systems (Colwell et al., 1999). Mincad Systems proposed two calibration procedures for the HSC cells. In this dissertation, the calibration procedure followed by Colwell et al. (1999) is used to compare the HSC cell results with the stress reduction factors found from the expected Bieniawki strength method. HSC cell calibration formula proposed by Mincad Systems and used by Colwell et al. (1999) employs a 
calibration factor $\mathrm{K}=1$ for a stress increase up to 715 psi and $\mathrm{K}=1.3$ for that portion of the stress increase above 715 psi.

Table 3.2 shows the comparison of the calibration methods proposed by Mincad and WVU (that was performed using a Bieniawski stress gradient). In this table, the average load reduction factor is calculated by averaging the load reduction factors applied to the raw stress cell data. The abutment load / total load ratio and abutment angles were calculated by using the laminated overburden load distribution method detailed in the next section below.

Table 3.2 Comparison of the calibration methods.

\begin{tabular}{|c|c|c|c|c|c|c|}
\hline \multirow{2}{*}{ Case } & \multicolumn{2}{|c|}{ Average Load Reduction Factor } & \multicolumn{2}{|c|}{ Abutment Load / Total Load } & \multicolumn{2}{|c|}{ Abutment Angle } \\
\cline { 2 - 7 } & Mincad & WVU & Mincad & WVU & Mincad & WVU \\
\hline$A U-1$ & 0.81 & 0.73 & 0.61 & 0.54 & 25 & 22 \\
\hline$A U-2$ & 1.00 & 1.00 & 0.17 & 0.17 & 21 & 21 \\
\hline$A U-3$ & 0.90 & 0.81 & 0.22 & 0.20 & 19 & 17 \\
\hline$A U-4$ & 0.81 & 1.00 & 0.39 & 0.48 & 16 & 19 \\
\hline$A U-5$ & 0.79 & 1.00 & 0.26 & 0.33 & 8 & 9 \\
\hline$A U-6$ & 0.88 & 0.87 & 0.35 & 0.31 & 11 & 10 \\
\hline
\end{tabular}

A matched pair t-test (Dowdy et al., 2004) was used to compare if the abutment angles calculated by the Mincad and WVU calibration methods are statistically different. In order to perform the test, first the difference between the calculated abutment angles using the two different calibration procedure (Mincad and WVU) for each case history was determined. Then, one sample t-test was performed to test if the mean of the differences was equal to zero. The null hypothesis $\left(\mathrm{H}_{0}\right)$ and the alternative hypothesis $\left(\mathrm{H}_{\mathrm{a}}\right)$ of t-test are:

$$
\begin{aligned}
& \mathrm{H}_{0}: \mu_{\mathrm{d}}=0 \\
& \mathrm{H}_{\mathrm{a}}: \mu_{\mathrm{d}} \neq 0
\end{aligned}
$$

where;

$\mu_{\mathrm{d}}=$ mean of the difference between the abutment angles calculated by Mincad and WVU calibration methods.

In order to determine if the one sample t-test is significant or not, test statistic $(t)$ is calculated by Equation 3.4. In Equation 3.4, " $\bar{y}$ " is the mean of the samples, " $\mu_{0}$ " is the population mean $\left(\mu_{0}\right.$ $=0$ ), "s" is the sample standard variation and " $n$ " is the sample size. Using Equation 3.4, the test 
statistic is calculated as $t=0.377965$. Using a significant level of $\alpha=0.05$ ( $95 \%$ confidence interval) and $5(\mathrm{v}=6-1)$ degrees of freedom, $\mathrm{t}_{0.025,5}=2.571$ is found from the critical $\mathrm{t}$ values table (Dowdy et al., 2004).

$$
\begin{aligned}
& \mathrm{t}=\frac{\overline{\mathrm{y}}-\mu_{0}}{\mathrm{~s} / \sqrt{\mathrm{n}}} \\
& t_{\frac{\alpha}{2}, n-1} \geq t \geq-t_{\frac{\alpha}{2}, n-1}
\end{aligned}
$$

The statistical test result showed that for these six cases there is not any significant difference in abutment angles calculated by the two methods at a significant level of 0.05 (95\% confidence level). This result implies that either the Mincad or the stress gradient calibration methods give essentially similar results.

\subsection{Abutment Extent and Abutment Angle Calculation}

After the calibrated stress profiles were determined using the calibration approach described above, the "measured" abutment extents and abutment angles were determined. Since none of the case histories physically measured to the extent of the abutment load, some type of abutment stress distribution had to be assumed and then this stress distribution was used to extrapolate the stress measurements to determine the "measured" abutment extent. For this determination of the abutment extent from the stress measurements; two different potential stress distributions were analyzed: 1) the laminated overburden stress distribution and 2) the square decay stress distribution.

Figure 3.2 shows typical stress change data collected from a two entry Australian longwall mine. The area LA represents the abutment load on the gateroad pillar and the area LB represents the abutment load on the adjacent solid coal. After the "calibration" of the stress cells as explained in the previous section, the areas LA and LB were numerically calculated by integrating the load under the curve (Simpsons rule). Then the LA / (LA+LB) ratio was calculated. 


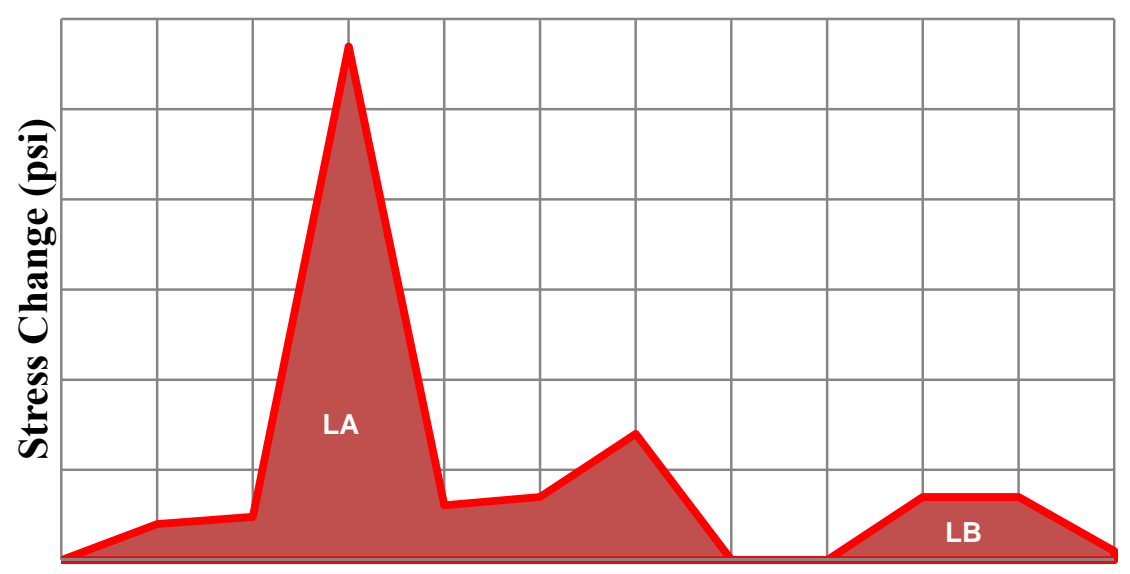

Distance From the Pillar Rib (ft)

Figure 3.2 Typical stress change data from a two entry mine.

For the laminated overburden stress distribution approach, Equation 3.6 gives the abutment stress magnitude $\left(\sigma_{1}\right)$ as a function of the distance from the panel rib (x) (Heasley, 1998).

$$
\sigma_{1}(x)=q \frac{P}{2} \sqrt{\frac{2 E_{s}}{E \lambda h}} e^{-\sqrt{\frac{2 E_{s}}{E \lambda h}}}
$$

where;

$\sigma_{1}=$ the abutment stress magnitude.

$\mathrm{q}=$ the insitu stress.

$\mathrm{P}=$ the width of the panel.

$\mathrm{E}_{\mathrm{s}}=$ the elastic modulus of the seam.

$\mathrm{E}=$ the elastic modulus of the overburden.

$\lambda=$ a parameter of the laminated model.

$\mathrm{h}=$ the seam thickness.

$\mathrm{X}=$ distance from the panel rib.

In this equation, the insitu stress (q) is determined as:

$$
\mathrm{q}=\gamma \mathrm{H}
$$

where:

$$
\begin{aligned}
& \gamma=\text { the overburden density } \\
& H=\text { the seam depth }
\end{aligned}
$$


and

$$
\lambda=\frac{\mathrm{t}}{\sqrt{12\left(1-\mathrm{v}^{2}\right)}}
$$

where:

$\mathrm{t}=$ the lamination thickness in the rock mass

$v$ = Poisson's Ratio of the rock mass

The percentage of the total measured load on the abutment pillar (n) for the two entry gate road in Figure 3.2 is calculated from the stress measurements as:

$$
\mathrm{n}=\frac{\mathrm{L}_{\mathrm{A}}}{\mathrm{L}_{\mathrm{A}}+\mathrm{L}_{\mathrm{B}}}
$$

To determine the lamination thickness which gives the same load percentage (n) of the side abutment load as measured in the field, first, the stress defined by the Equation 3.6 is integrated over the $\mathrm{x}_{1}$ distance to calculate the load on abutment pillar (see Figure 3.3).

$$
\mathrm{L}_{\mathrm{A}}=\int_{0}^{\mathrm{x}_{1}} \sigma_{\mathrm{l}}(\mathrm{x}) \mathrm{dx}=-\mathrm{mq} \frac{\mathrm{p}}{2}\left(\mathrm{e}^{-\sqrt{\frac{2 \mathrm{E}_{\mathrm{s}}}{\mathrm{E} \mathrm{h} h}} \mathrm{x}_{1}}-1\right)
$$

Second, Equation 3.6 is also integrated over the $\mathrm{x}_{2}$ distance to calculate the total abutment load on the abutment pillar and solid coal (Figure 3.3).

$$
\mathrm{L}_{\mathrm{A}}+\mathrm{L}_{\mathrm{B}}=\int_{0}^{\mathrm{x}_{2}} \sigma_{\mathrm{l}}(\mathrm{x}) \mathrm{dx}=-\mathrm{mq} \frac{\mathrm{p}}{2}\left(\mathrm{e}^{-\sqrt{\frac{2 \mathrm{E}_{\mathrm{S}}}{\mathrm{E} \lambda \mathrm{h}}} \mathrm{x}_{2}}-1\right)
$$

Then the percentage of the abutment load on the abutment pillar can be determined by dividing Equation 3.10 by Equation 3.11 as:

$$
\mathrm{n}=\frac{-m q \frac{p}{2}\left(e^{-\sqrt{\frac{2 E_{S}}{E \lambda h}} x_{1}}-1\right)}{-m q \frac{p}{2}\left(e^{-\sqrt{\frac{2 E_{S}}{E \lambda h}} x_{2}}-1\right)}
$$

Simplifying, and substituting back in for $\lambda$, we get:

$$
0=n e^{-\sqrt{\frac{2 \mathrm{E}_{\mathrm{s}} \sqrt{12\left(1-\mathrm{v}^{2}\right)}}{\mathrm{Eht}}} \mathrm{x}_{2}}-\mathrm{e}^{-\sqrt{\frac{2 \mathrm{E}_{\mathrm{s}} \sqrt{12\left(1-\mathrm{v}^{2}\right)}}{\mathrm{Eht}}} \mathrm{x}_{1}}-\mathrm{n}+1
$$


Equation 3.13 can then be solved numerically for the lamination thickness which gives a loading percentage that matches the " $n$ " value determined by field measurements. The resultant lamination thickness is then used in Equation 3.14 derived by Heasley et al. (2010) to calculate the extent of the abutment distance (D).

$$
\mathrm{D}_{\mathrm{n}}=-\ln (1-\mathrm{n}) \sqrt{\frac{\mathrm{Eht}}{2 \mathrm{E}_{s} \sqrt{12\left(1-\mathrm{v}^{2}\right)}}}
$$

In order to back calculate the abutment angle, the ratio of the total abutment load over the total panel load (qp/2) needs to be known. This ratio can be estimated by looking at the measured load on pillar $\mathrm{A}\left(\mathrm{L}_{\mathrm{A}}\right)$ versus the amount of load on pillar A without any gob loading (see Equation 3.12).

$$
\mathrm{m}=-\frac{\mathrm{L}_{\mathrm{A}}}{\mathrm{q} \frac{\mathrm{p}}{2}\left(\mathrm{e}^{-\sqrt[2 \mathrm{E}_{\mathrm{s}}]{\mathrm{E \lambda \textrm {h } ^ { \mathrm { h } }}}-1}\right)}
$$

Finally, the value of the abutment angle can be back calculated from the ratio " $\mathrm{m}$ " according to the subcritical or supercritical panel formulas.

For the square decay stress distribution approach, Equation 2.18, gives the abutment stress distribution $\left(\sigma_{\mathrm{a}}\right)$ as a function of the full abutment extent (D) and the distance (x) from the panel rib. The calculated load on the abutment pillar for the two entry gate road system can be determined by integrating Equation 2.18 over the distance $\mathrm{x}_{1}$ from the panel edge (see Figure $3.3)$.

$$
L_{A}=\int_{0}^{x_{1}} \sigma_{a}(x) d x=\frac{3 L_{s}}{D^{3}}\left(D^{2} x_{1}-D x_{1}^{2}+\frac{x_{1}^{3}}{3}\right)
$$

Likewise, Equation 2.18 is integrated over the distance $\mathrm{x}_{2}$ from the panel rib to calculate the total load on the abutment pillar and solid coal.

$$
\mathrm{L}_{\mathrm{A}}+\mathrm{L}_{\mathrm{B}}=\int_{0}^{\mathrm{x}_{2}} \sigma_{\mathrm{a}}(\mathrm{x}) \mathrm{dx}=\frac{3 \mathrm{~L}_{\mathrm{s}}}{\mathrm{D}^{3}}\left(\mathrm{D}^{2} \mathrm{x}_{2}-\mathrm{Dx}_{2}^{2}+\frac{\mathrm{x}_{2}^{3}}{3}\right)
$$

Then the percentage of the abutment load on the abutment pillar can be determined by dividing Equation 3.16 by Equation3.17 as:

$$
\mathrm{n}=\frac{\frac{3 L_{s}}{D^{3}}\left(D^{2} x_{1}-D x_{1}^{2}+\frac{x_{1}^{3}}{3}\right)}{\frac{3 L_{S}}{D^{3}}\left(D^{2} x_{2}-D x_{2}^{2}+\frac{x_{2}^{3}}{3}\right)}
$$


Finally, Equation 3.19 is solved numerically for the full abutment extent (D).

$$
0=n-\frac{D^{2} x_{1}-D x_{1}^{2}+\frac{x_{1}^{3}}{3}}{D^{2} x_{2}-D x_{2}^{2}+\frac{x_{2}^{3}}{3}}
$$

After the calculation of the inverse squared abutment extent, the total abutment load $\left(\mathrm{L}_{\mathrm{S}}\right)$ can be calculated by using the measured abutment load for pillar A and solving Equation 3.16 for the associated side abutment load.

$$
L_{S}=\frac{L_{A} D^{3}}{3\left(D^{2} x_{1}-D x_{1}^{2}+\frac{x_{1}^{3}}{3}\right)}
$$

Finally, the abutment angle can be back calculated from the values of " $L_{S}$ " according to the appropriate subcritical or supercritical panel formulas.

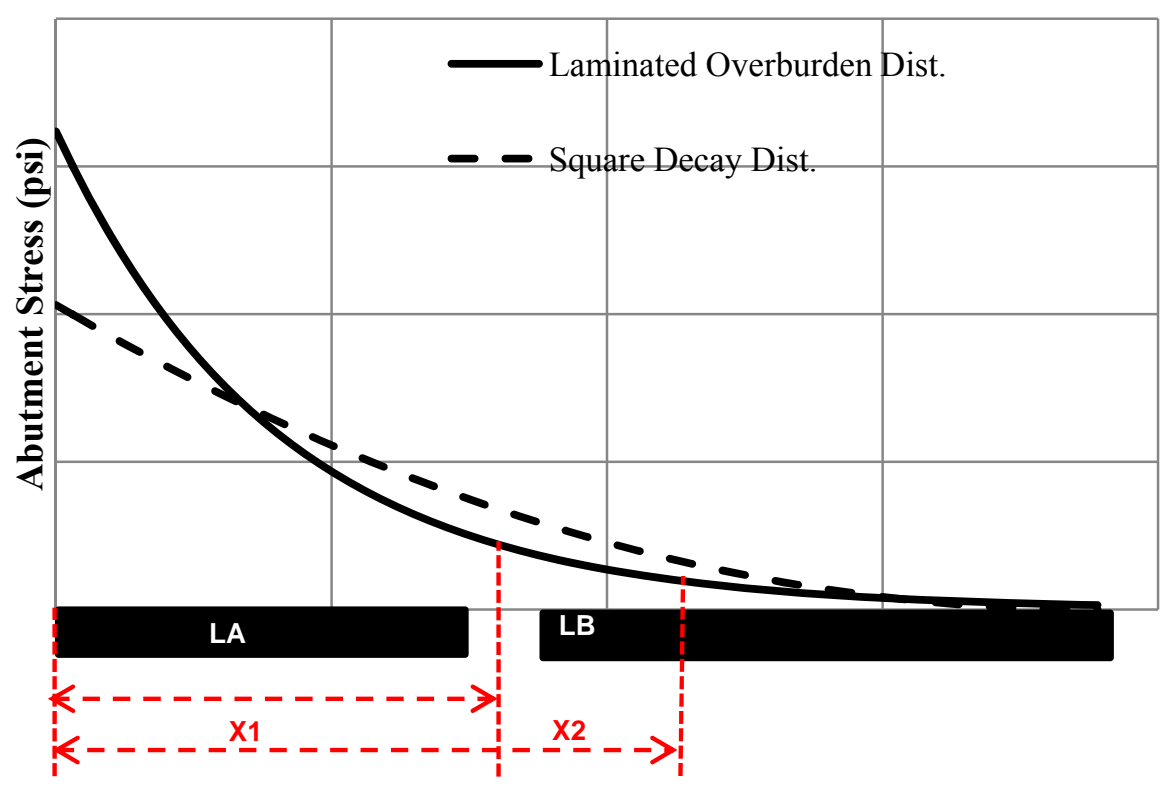

Figure 3.3 Analytical stress distribution functions.

\subsection{Results of the Analysis}

\subsubsection{Re-analysis of the Abutment Extent}

The first parameter to be examined in this study was the extent of the abutment load. Figure 3.4 shows a comparison of the back calculated abutment extents (for $90 \%$ of the total abutment load) for 13 of the case histories with sufficient field data. The red, green and black colors represent the abutment extents calculated by: ARMPS, the square decay fit to the field data and the laminated model fit to the field data, respectively. Both ARMPS and the square decay 
methods use the same stress distribution function and give fairly similar results. The difference between them is: ARMPS uses the full abutment extent (D) calculated by Equation 2.17, while the square decay method specifically calculates the full abutment extent for each of the individual stress measurement.

All three methods showed very similar trends. The laminated model gave the largest abutment extents and the square decay formula gave the smallest abutment extents. The ARMPS method calculated the abutment extent slightly larger than square decay method and considerable lower than the laminated model. For low panel depths, the square decay method calculated abutment extent less than the ARMPS method. However, as the panel depth increased, the square decay method calculated the abutment extent similar to the ARMPS method.

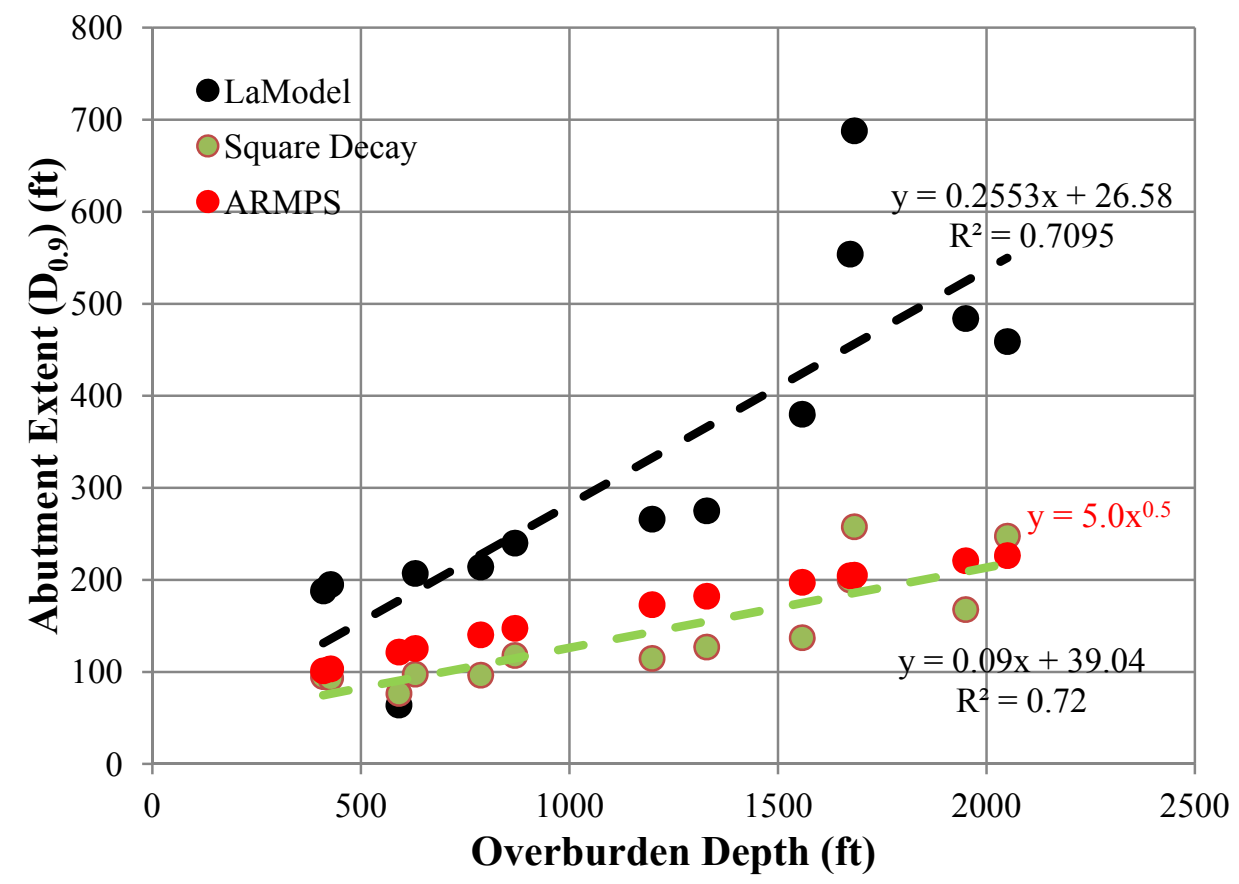

Figure 3.4 Extent of the abutment zone containing $90 \%$ of the abutment load.

In all of the abutment extent calculations, the abutment stress levels asymptotically approach zero the further the location is from the edge of the panel. Therefore, the location of $90 \%$ of the abutment load is very sensitive to small changes in the parameters to the equations. A more stable location for back-calculation can be found in the steeper section of the stress decay curves, for instance near the point of $50 \%$ of the abutment load. To investigate the impact of changing the loading percentage on the calculated abutment extent, a comparison of the back calculated abutment extents for $50 \%$ of the total abutment load for 13 of the case histories was performed 
(see Figure 3.5). The red, green, black and blue colors represent the abutment extents calculated by: ARMPS, the square decay function, the laminated function and the laminated model calibrated as proposed by Heasley (2010) methods, respectively.

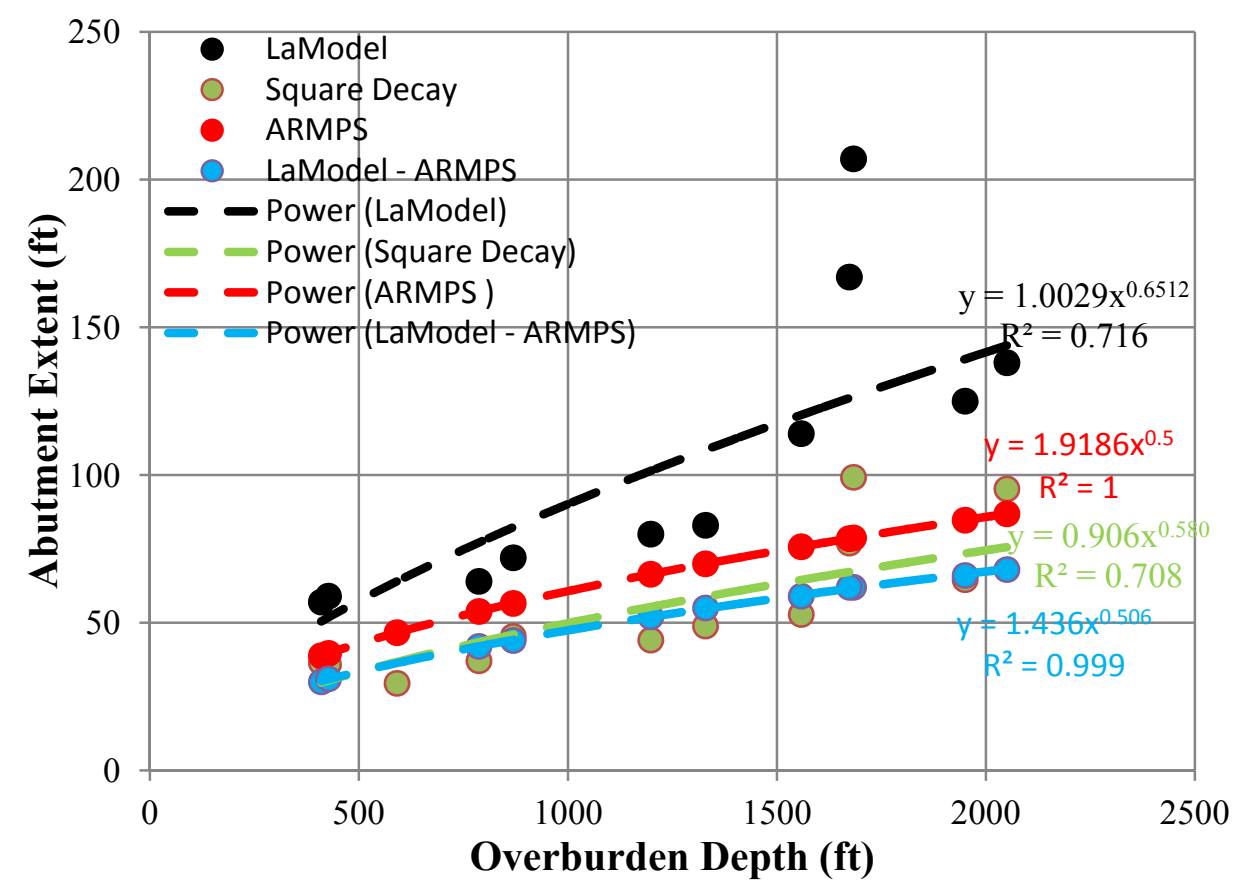

Figure 3.5 Extent of the abutment zone containing $50 \%$ of the abutment load.

Both the square decay function and the calibrated laminated model methods calculated very similar abutment extends for $50 \%$ of the abutment load, and these two methods generally predicted more load closer to the panel than either the ARMPS or pure laminated function. However, as shown in Figure 3.4 and 3.5, the laminated model predicted the load transfer distance longer than the square decay method. This means that square decay function put more load on the gate road pillars than laminated model. The laminated model with lamination thickness calibration method proposed by Heasley et al. (2010) puts a very similar amount of load on to the gate road pillars as the square decay function (Figure 3.5).

Figure 3.6 shows just the comparison between the square decay fit to the field data and the ARMPS method from Figure 3.4. The green points represent the field data, and the solid green line represents the linear least-square best-fit line to the field data. The upper and lower limits of the $95 \%$ confidence interval of the best fit line are shown by the dotted green lines. The red line represents the ARMPS abutment extent $\left(\mathrm{D}_{0.9}\right)$ prediction equation. ARMPS predicts the abutment extent very close to the upper limit of the confidence interval from the square-decay 
field data. For depths less than $600 \mathrm{ft}$ and higher than $1500 \mathrm{ft}$, ARMPS prediction is inside the confidence interval.

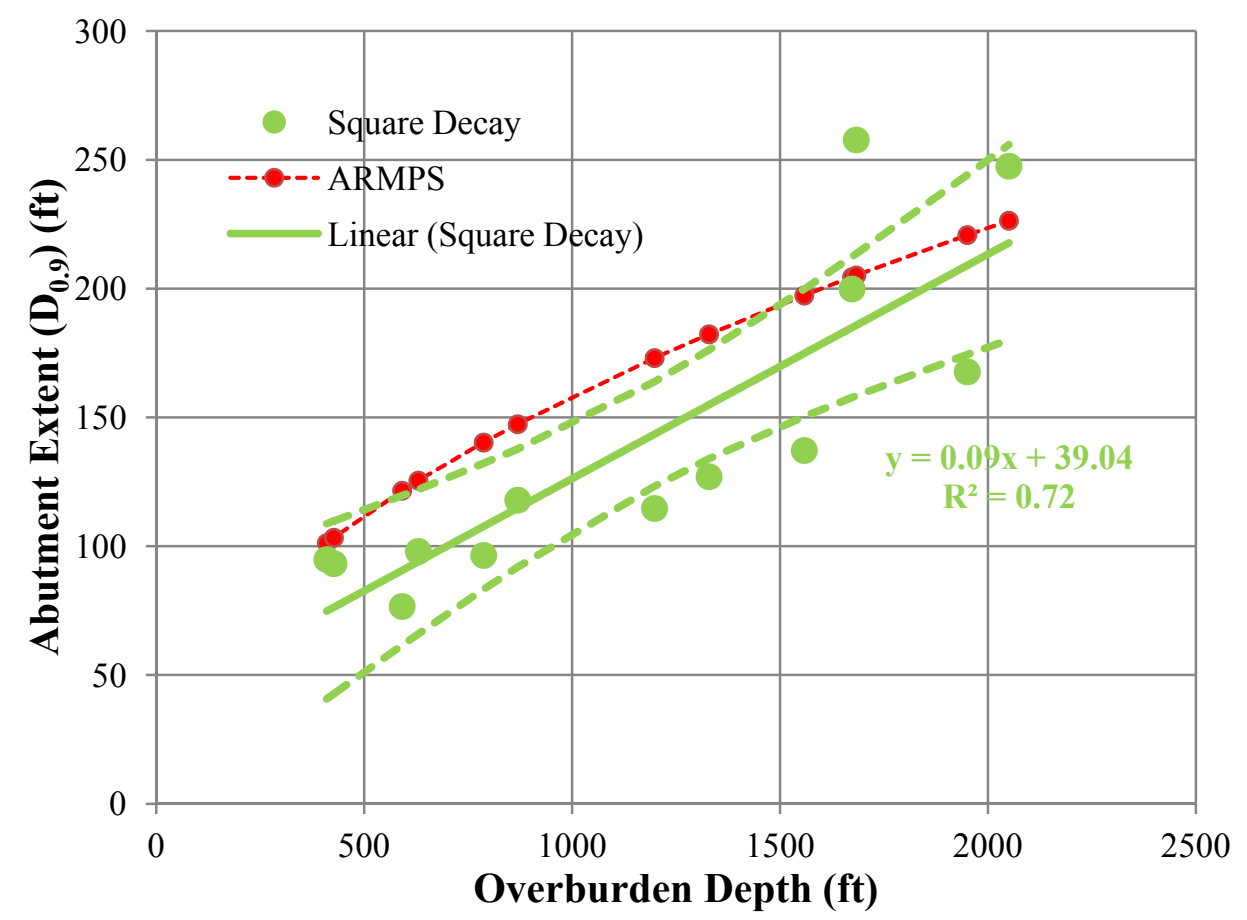

Figure 3.6 Comparison of the $\mathrm{D}_{0.9}$ extent of the abutment zone back calculated from square decay method with original ARMPS method.

As a result of this abutment extent analysis of the in-situ stress measurement, it appears that traditional abutment extent formula given in Equation 2.17 very closely matches the square decay fit to the field data used in this analysis. Stated another way, the field data in this analysis appear to support the abutment extent as traditionally calculated by Equation 2.17.

\subsubsection{Re-analysis of the Abutment Angle}

In order to compare the effect of the different load distribution curves on the total abutment load magnitude, the abutment angles back calculated from the laminated model and the square decay laminated model stress distribution functions were compared (see Table 3.3). In general, it was found that the laminated model calculated the abutment angles slightly higher than the square decay method. A matched pair t-test (Dowdy et al., 2004) was used to compare if the abutment angles back calculated by the laminated model and the square decay curves are statistically different (Table 3.5). The differences between the abutment angles calculations were statistically significant (statistically different) at a significant level of 0.05 ( $95 \%$ confidence level). 
Table 3.3 Comparison of abutment angles back calculated using LaModel and Square Decay stress distribution functions.

\begin{tabular}{|c|c|c|c|c|c|}
\hline \multirow{2}{*}{ Case } & \multicolumn{3}{|c|}{ Abutment Angles (Deg.) } & \multirow{2}{*}{ OB Depth (ft) } & \multirow{2}{*}{ Panel Width (ft) } \\
\hline & LaModel & Square Decay & LaModel Difference & & \\
\hline$A U-1$ & 25 & 22 & +3 & 869 & 656 \\
\hline$A U-2$ & 21 & 19 & +2 & 410 & 902 \\
\hline$A U-3$ & 19 & 17 & +2 & 427 & 656 \\
\hline$A U-4$ & 16 & 16 & 0 & 591 & 427 \\
\hline$A U-5$ & 8 & 8 & 0 & 1558 & 656 \\
\hline$A U-6$ & 11 & 9 & +2 & 787 & 476 \\
\hline$A U-7$ & 14 & 12 & +2 & 1329 & 820 \\
\hline$A U-8$ & 15 & 11 & +4 & 1683 & 745 \\
\hline$A U-9$ & 11 & 10 & +1 & 1198 & 820 \\
\hline$A U-10$ & 11 & 10 & +1 & 1673 & 778 \\
\hline US-1 & 10 & 8 & +2 & 1950 & 640 \\
\hline US-2 & 8 & 8 & 0 & 2050 & 600 \\
\hline & & Average & 1.58 & & \\
\hline
\end{tabular}

Table 3.4 Comparison of abutment angles back calculated by using Square Decay and Calibrated LaModel load distribution functions.

\begin{tabular}{|c|c|c|c|}
\hline \multirow{2}{*}{ Case } & \multicolumn{3}{|c|}{ Abutment Angles (Deg.) } \\
\cline { 2 - 4 } & Square Decay & Calibrated LaModel & Square Decay Difference \\
\hline$A U-1$ & 22 & 22 & 0 \\
\hline$A U-2$ & 19 & 18 & 1 \\
\hline$A U-3$ & 17 & 16 & -1 \\
\hline$A U-4$ & 16 & 17 & 0 \\
\hline$A U-5$ & 8 & 8 & 0 \\
\hline$A U-6$ & 9 & 9 & 0 \\
\hline$A U-7$ & 12 & 12 & 2 \\
\hline$A U-8$ & 11 & 9 & 0 \\
\hline$A U-9$ & 10 & 10 & 1 \\
\hline$A U-10$ & 10 & 9 & 0 \\
\hline$U S-1$ & 8 & 8 & 0.42 \\
\hline$U S-2$ & 8 & 7 & \\
\hline
\end{tabular}


Similarly, the abutment angles back calculated from the square decay model and the calibrated LaModel (as proposed by Heasley et. al (2010)) were compared (see Table 3.4 and Table 3.5). The differences between the abutment angles calculations were statistically nonsignificant.

Although the abutment angles calculated by the square-decay function and the laminated model are statistically different, the average difference is only $1.6^{\circ}$. This $1.6^{\circ}$ difference only changes the magnitude of the total abutment load very slightly, and for most practical purposes, the two methods essentially calculate the same abutment load.

Table 3.5 Matched pair t-test results.

\begin{tabular}{|c|c|c|c|c|c|}
\hline Comparison & DOF & $\begin{array}{c}\text { Significance } \\
\text { Level }\end{array}$ & Test Statistic & $\begin{array}{c}\text { Critical t } \\
\text { Value }\end{array}$ & Result \\
\hline $\begin{array}{c}\text { LaModel vs. Square } \\
\text { Decay }\end{array}$ & 11 & 0.05 & 4.4228 & 2.201 & $\mu_{\mathrm{d}} \neq 0$ \\
\hline $\begin{array}{c}\text { Square Decay vs. } \\
\text { Calibrated LaModel }\end{array}$ & 11 & 0.05 & 1.8202 & 2.201 & $\mu_{\mathrm{d}}=0$ \\
\hline
\end{tabular}

Although it has been shown that the square-decay function and the laminated overburden function calculate similar abutment angles for the field data, the results of these calculations for deeper mines do not match the average $21^{\circ}$ abutment angle used in ALPS and ARMPS. Figure 3.7 shows the results for the abutment angles back calculated from the square-decay stress distribution curve. For the mines deeper than about $900 \mathrm{ft}$, it can be seen that the abutment angle values are all lower than $21^{\circ}$ and distributed fairly evenly between the maximum value of $18^{\circ}$ and minimum value of $6^{\circ}$, with the mean of $10^{\circ}$. For the mines with overburden depth less than $900 \mathrm{ft}$, the scatter is much larger, but the abutment angles are evenly distributed with a mean of $21^{\circ}$. 


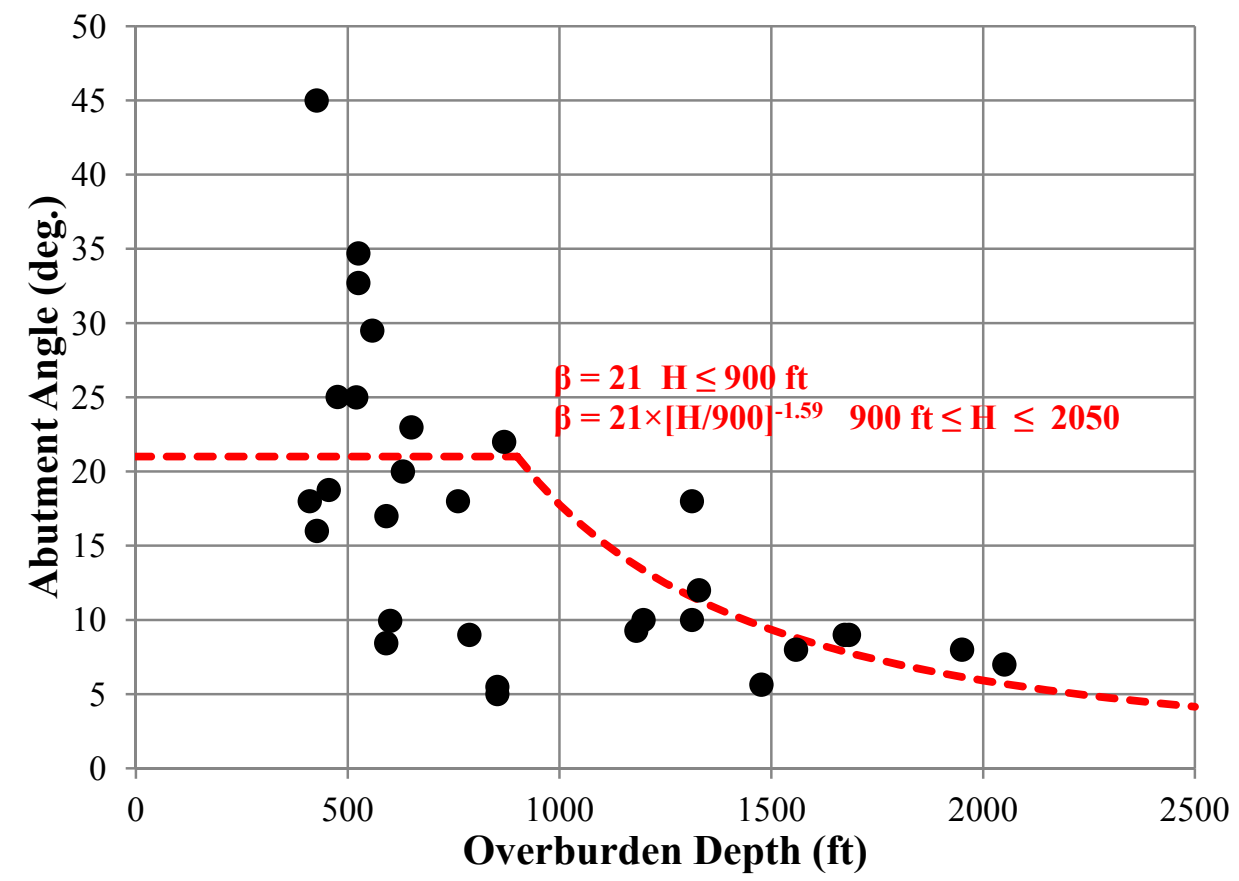

Figure 3.7 Abutment angles calculated using the square decay model.

Based on the field data analyzed in this paper, the proposed abutment angle determination is shown as the red line in Figure 3.7 (Table 3.6). When the overburden depth is less than $900 \mathrm{ft}$, a constant abutment angle of $21^{\circ}$ is proposed. Between $900 \mathrm{ft}$ and $2050 \mathrm{ft}$, an abutment angle $(\beta)$ that decreases with a continuous nonlinear power function of the depth $(\mathrm{H})$ from $21^{\circ}$ is proposed. Table 3.6 Proposed abutment angle concept.

\begin{tabular}{|c|c|}
\hline Overburden Depth (H) & Abutment Angle (deg.) \\
\hline $\mathrm{H} \leq 900 \mathrm{ft}$ & 21 \\
\hline $900 \mathrm{ft} \leq \mathrm{H} \leq 2050 \mathrm{ft}$ & $21 \times\left[\frac{\mathrm{H}}{900}\right]^{-1.59}$ \\
\hline
\end{tabular}

(This second equation was derived by fixing the starting point at $900 \mathrm{ft}$ deep and $21^{\circ}$, and then performing a least-square error fit to the measured abutment angles above $900 \mathrm{ft}$ deep.) 


\section{Chapter 4 Summary and Conclusions}

\subsection{Objective}

In the U.S. underground coal industry, ALPS, ARMPS and LaModel programs are generally used to design the pillars to ensure the global stability of a mine. These design programs mainly perform three functions: 1) predict the overburden load on the pillars, 2) predict the load bearing capacity of the pillars and 3) calculate the stability factor. Accurate prediction of the overburden load largely depends on the accuracy of the abutment load calculations. In the ALPS, ARMPS and LaModel, the magnitude of the abutment loading adjacent to a gob area is calculated using an "abutment angle" concept and the extent of the abutment loading is determined as solely a function of depth from an empirically derived equation (Equation 2.17). The original in-situ stress measurement studies used to develop the empirical abutment extent equation and recommended abutment angle value were from early 1980s and 1990s. However, current mines have significantly different panel dimensions than the mines where these older stress measurements were collected and used to derive the original empirical abutment extent formula (Equation 2.17) and the average $21^{\circ}$ abutment angle.

It is the goal of this dissertation to improve the current empirical $21^{\circ}$ abutment angle concept and abutment extent equation from the most recent in-situ stress measurements representing the current mining conditions. In this dissertation, the traditional calculations for the abutment extent and abutment loading are re-examined using a current database of recent in-situ stress measurements from 12 case studies with an additional 18 supplementary case studies.

\subsection{Final Conclusions}

The re-analysis of the extent of the abutment zone in this dissertation showed that the laminated overburden model calculated much larger abutment extents than the original ALPS/ARMPS equation and that the square decay function calculated smaller abutment extents, but close to the original equation proposed by Peng and Chiang (see Equation 2.17). The large difference between the calculated abutment extents stems from the natural shape of the analytical load distribution curves that were used. As a result of the abutment extent analysis of the case histories in this dissertation, it was determined that the original empirical abutment extent 
formula in conjunction with the original ALPS square-decay stress distribution function (Equation 2.17) sufficiently matched the old and new field data; therefore, it is recommended to use equations 2.17, 2.18 and 2.20 in abutment extent and abutment distribution calculations.

The re-analysis of the magnitude of the abutment load (as represented by the abutment angle) performed in this paper showed that for higher overburden depths, the re-analyzed abutment angle appears to be much less than the $21^{\circ}$ average traditional used. Based on the field data analyzed in this paper, a new abutment angle calculation with depth is proposed (see Table 3.6). When the overburden depth is less than $900 \mathrm{ft}$, the $21^{\circ}$ abutment angle proposed by Mark (1992) should be used. It is known from the ARMPS analysis that the $21^{\circ}$ abutment angle works fine for the shallow cover cases (Mark, 2010). However, between depths of 900 to $2050 \mathrm{ft}$, the abutment angle should be calculated with the nonlinear power function shown in Table 3.6.

\subsection{Ideas for Additional Research}

The effect of the panel width, overburden geology and mining height on the abutment extent and abutment angle values were not found to be significant with the current data cases. However, it is believed by the author of this dissertation that certainly the panel width and the geology of the overburden have an important effect on these two values. However, in the database of stress measurement used in this dissertation, the panel widths and geologies may not have varied enough to establish a significant difference. In addition, it should be noted that in the database there are not any case histories from the deep western U.S. mines. It is known that much longer abutment extents than predicted by the original abutment extent formula (Equation 2.17) have been observed in the some of the Western U.S. mines (Haramy and Kneisley, 1989; Lu, 1982; Goodrich et al., 1999).

In the future, this database of stress measurements can be extended by including cases from Western U.S. mines and other areas. In addition, it is desired to test the validity of the newly derived abutment angle calculation. One possible method to do this validation would be to reanalyze the large ARMPS database using the new abutment angle calculation and see if there is a better classification of successes and failures. 


\section{References}

1. Babcock, C.O. 1980. Equations for the Analysis of Borehole Pressure Cell Data. In Proceedings of the $27^{\text {th }}$ U.S. Symposium on Rock Mechanics, University of Alabama, Tuscaloosa, AL, pp. 512-519.

2. Barron, K. 1984. An Analytical Approach to Design of Coal Pillars. CIM Bulletin, Vol. 77, No. 868, August, pp. 37-44.

3. Barron, K. and Y. Pen. 1992. A Revised Model for Coal Pillars. Coal Pillar Mechanics: Theoretical Models and Field Measurements Compared. In Proceedings of the International Workshop on Coal Pillar Design and Mechanics, U.S. Bureau of Mines IC 9315, pp. 144157.

4. Bieniawski, Z.T. 1981. Improved Design of Coal Pillars for U.S. Mining Conditions. In Proceedings of the $1^{\text {st }}$ International Conference on Ground Control in Mining, West Virginia University, Morgantown, WV, July, pp. 13-22.

5. Bieniawski, Z.T. 1992. A Method Revisited: Coal Pillar Strength Formula Based on Field Investigations. In Proceedings of the Workshop on Coal Pillar Mechanics and Design. BuMines IC 9315, pp. 158-165.

6. Brady, B.H.G. and E.T. Brown. 2004. Rock Mechanics for Underground Mining. $3^{\text {rd }}$ Edition. Kluwer Academic Publishers, 628 pp.

7. Carr, F. and A.H. Wilson. 1982. A New Approach to the Design of Multi-Entry Developments for Retreat Longwall Mining. In Proceedings of the $1^{\text {st }}$ International Conference on Ground Control in Mining, West Virginia University, Morgantown, WV, July, pp. 2-12.

8. Chase F.E., C. Mark and K.A. Heasley. 2002. Deep Cover Pillar Extraction in the US. In

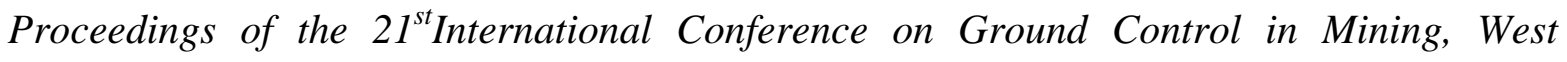
Virginia University, Morgantown, WV, July, pp. 68-80.

9. Choi, D.S. and D.L. McCain. 1980. Design of Longwall Systems. Trans AIME-SME, Vol. 258, pp. 1761-1764.

10. Coates, D.F. 1981. Rock Mechanics Principles. CANMET Energy, Mines and Resources Canada, $874 \mathrm{pp}$. 
11. Colwell, M., R. Frith and C. Mark. 1999. Analysis of Longwall Tailgate Serviceability (ALTS): A Chain Pillar Design Methodology for Australian Conditions. In Proceedings of the Second International Workshop on Coal Pillar Mechanics and Design, NIOSH: IC 9448, pp. 33-48.

12. Dowdy, S., S. Weardon and D. Chilko. 2004. Statistics for Research. $3^{\text {rd }}$ ed. Hoboken, New Jersey: John Wiley \& Sons, pp. 640.

13. Esterhuizen, E., C. Mark and M. Murphy. 2010. The Ground Response Curve and Its Impact

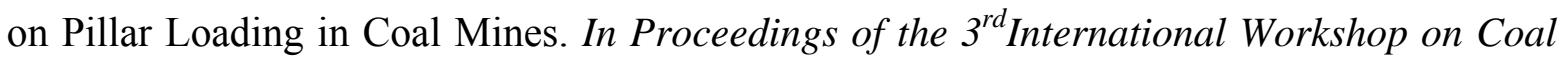
Pillar Mechanics and Design, U.S. NIOSH, pp. 123-131.

14. Gale, W. 1992. A Pillar Design Approach. In Proceedings of the International Workshop on Coal Pillar Mechanics and Design, U.S. Bureau of Mines IC 9315, pp. 188-195.

15. Gale, W. 2010. Stress Conditions and Failure Mechanics Related to Coal Pillar Strength. In

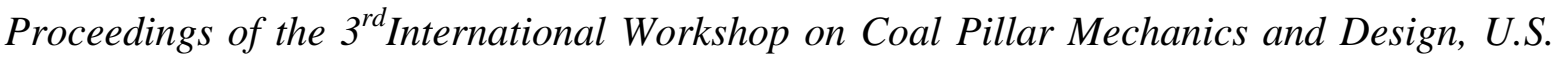
NIOSH, pp. 30-37.

16. Geokon, Inc. 2004. Instructional Manual Vibrating Wire Stressmeter 4300 Series (EX, BX, $N X), 19 \mathrm{pp}$.

17. Goodrich, R.R., J.F.T. Agapito, C. Pollastro, L. LaFrentz and K. Fleck. 1999. Long Load Transfer Distances at the Deer Creek Mine. In Proceedings of the Rock Mechanics for Industry, $37^{\text {th }}$ U.S. Symposium. Rotterdam, The Netherlands: Balkema, pp. 517-523.

18. Haramy, K.Y. and R.O. Kneisley. 1989. Comparative Study of Western U.S. Longwall Panel Entry Systems. In Proceedings of the $30^{\text {th }}$ U.S. Symposium on Rock Mechanics, West Virginia University, Morgantown, WV, June, pp. 125-132.

19. Hawkes, I. and W.V. Bailey. 1973. Low Cost Cylindrical Stress Gage. U.S. Bureau of Mines OFR, pp. 54-75.

20. Heasley, K.A. 1989. Understanding the Hydraulic Pressure Cell. In Proceedings of the $30^{\text {th }}$ U.S. Symposium on Rock Mechanics, Morgantown, WV, pp. 485-492.

21. Heasley, K.A. 1998. Numerical Modeling of Coal Mines with a Laminated DisplacementDiscontinuity Code. Ph.D. Dissertation, Colorado School of Mines, CO.

22. Heasley, K.A., 2000. The Forgotten Denominator, Pillar Loading. In Proceedings of the $4^{\text {th }}$ North American Rock Mechanics Symposium, Seattle, WA, July 31-Aug. 3, p. 457-464. 
23. Heasley, K.A., M.M. Sears, I.B. Tulu, C.H. Calderon-Arteaga and L.W. Jimison II. 2010 Calibrating the LaModel Program for Deep Cover Pillar Retreat Coal Mining. In Proceedings of the $3^{\text {rd }}$ International Workshop on Coal Pillar Mechanics and Design, Morgantown WV, July 26, pp. 47-57.

24. Hoch, M.T., G.J., Karabin and J.M. Kramer. 1992. MSHA's Simple Technique for Predicting Stress Distribution in a Mine Panel. Coal Pillar Mechanics: Theoretical Models and Field Measurements Compared. In Proceedings of the International Workshop on Coal Pillar Mechanics and Design, U.S. Bureau of Mines IC 9315, pp. 61-72.

25. Holland, C.T. and F.L. Gaddy. 1957. Some Aspects of Permanent Support of Overburden on Coal Beds. In Proceedings of West Virginia Coal Mining Institute, pp 43-66.

26. Holland, C.T., 1973. Mine Pillar Design. Mining Engineering Handbook, A. B. Cummins and I. A. Given, eds. SME-AIME, pp. 13-96 to 13-118.

27. King, H.J. and B.N. Whittaker. 1971. A Review of Current Knowledge on Roadway Behavior. In Proc. Symp. on Roadway Strata Control, IMM, London, pp. 73-87.

28. Kramer, J.M. 1996. The Use of Fracture Mechanics to Predict the Stress Distribution in Coal Mine Pillars. M.S. Dissertation, West Virginia University, WV.

29. Kripakov, N.P. 1981. Analysis of Pillar Stability on Steeply Pitching Seam Using the Finite Element Method. Bureau of Mines RI 8579, 33 pp.

30. Larson, M.K. and J.K Whyatt. 2012. Load-Transfer-Distance Calibration of a Coal Panel Scale Model: A Case Study. In Proceedings of the 31 ${ }^{\text {st International Conference on Ground }}$ Control in Mining, West Virginia University, Morgantown, WV, July, (in press).

31. Lu, P.H. 1982. Rock Mechanics Instrumentation and Monitoring for Ground Control around Longwall Panels. In Proceedings of International Symposium on State-of-the-Art of Ground Control in Longwall Mining and Mining Subsidence, Hawaii, U.S.A., September, pp.1-8.

32. Lu, P.H. 1984. Mining-Induced Stress Measurements with Hydraulic Borehole Pressure Cells. In Proceedings of the $25^{\text {th }}$ U.S. Symposium on Rock Mechanics, Northwest. University, Evanston, IL, pp. 204-211.

33. Maleki, H.N., M. Moon and J.F.T. Agapito.1987. Mine Layout Design for Ground Bump Control. In Proceedings of the $6^{\text {th }}$ International Conference on Ground Control in Mining, West Virginia University, Morgantown, WV, June, pp. 8. 
34. Maleki, H.N. 1992. In-Situ Pillar Strength and Failure Mechanism for U.S. Coal Seams. In Proceedings of the International Workshop on Coal Pillar Mechanics and Design, U.S. Bureau of Mines IC 9315, pp. 73-77.

35. Mark, C. 1987. Analysis of Longwall Pillar Stability. Ph.D. Dissertation, The Pennsylvania State University, PA.

36. Mark, C., 1992. Analysis of Longwall Pillar Stability (ALPS): an update. In Proceedings of the Workshop on Coal Pillar Mechanics and Design. BuMines IC 9315, pp. 238-249.

37. Mark, C. and A.T. Iannacchione. 1992. Coal Pillar Mechanics: Theoretical Models and Field Measurements Compared. In Proceedings of the International Workshop on Coal Pillar Mechanics and Design, U.S. Bureau of Mines IC 9315, pp. 78-93.

38. Mark, C. and F.E. Chase. 1997. Analysis of Retreat Mining Pillar Stability. Paper in New Technology for Ground Control in Retreat Mining: In Proceedings of the NIOSH Technology Transfer Seminar. NIOSH IC 9446, pp. 17-34.

39. Mark, C., F.E. Chase and D. M. Pappas. 2003. Reducing the Risk of Ground Falls During Pillar Recovery. SME Transactions, Vol 314, pp. 153-160 (formerly SME Preprint 03-137).

40. Mark, C. 2009. Deep Cover Pillar Recovery in the US. In Proceedings of the $28^{\text {th }}$ International Conference on Ground Control in Mining, West Virginia University, Morgantown, WV, July, pp. 1-9.

41. Mark, C., 2010. ARMPS 2010: Pillar Design for Deep Cover Retreat Mining. In Proceedings of the Second International Workshop on Coal Pillar Mechanics and Design, NIOSH, pp. 106-122.

42. Obert, L. and W.I. Duvall. Rock Mechanics and the Design of Structures in Rocks. Wiley, New York. 1967, 650 pp.

43. Peng, S.S. and H.S. Chiang. 1984. Longwall Mining. $1^{\text {st }}$ edition John Wiley \& Sons, 708 pp.

44. Peng, S.S, S.M. Hsiung. 1984. Development of Roof Control Criteria For Underground Longwall Mining. Final Report WV-80-MNG, West Virginia University Department of Mining Engineering.

45. Peng, S.S. 2006. Longwall Mining. $2^{\text {nd }}$ edition John Wiley \& Sons, 708 pp.

46. Peng, S.S. 2008. Coal Mine Ground Control. $3^{\text {rd }}$ edition, Department of Mining Engineering, West Virginia University, 750 pp. 
47. Salamon, M.D.G. and A.H. Munro. 1967. A Study of the Strength of Coal Pillars. Journal of South African Institute of Mining and Metallurgy. 68:56-67.

48. Salamon, M.D.G. 1992. Strength and Stability of Coal Pillars. In Proceedings of the International Workshop on Coal Pillar Design and Mechanics, U.S. Bureau of Mines IC 9315, pp. 94-121.

49. Salamon, M.D.G and H. Wagner.1985. Practical Experiences in the Design of Coal Pillars.

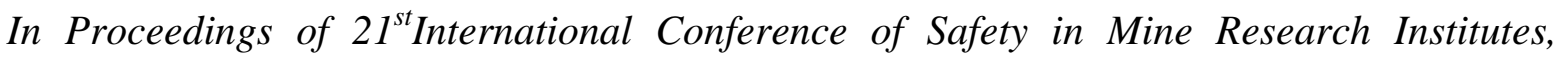
Sydney, Australia, pp. 3-9.

50. Sheorey, P.R., M.N. Das, S.K. Bordia and B. Singh. 1986. Pillar Strength Approaches Based on a New Failure Criterion for Coal Seams. International Journal of Mining Geology Engineering, No. 4, pp. 41-55.

51. Skiles, M.E. and K.G. Stricklin. 2009. General Guidelines for the Use of Numerical Modeling to Evaluate Ground Control Aspects of Proposed Coal Mining Plans. Mine Safety and Health Administration Program Information Bulletin No. P09-03, March 16, 2009, U.S. Department of Labor, 7 pp.

52. Su, D. and G.J. Hasenfus. 1990. Intrinsic Response of Borehole Pressure Cells Laboratory Calibration and Nonlinear FEM Simulation. In Proceedings of the $9^{\text {th }}$ International Conference on Ground Control in Mining, West Virginia University, Morgantown, WV, July, pp. 260-271.

53. Vandergrift, T. and D. Conover. 2010. Assessment of Gate Road Loading under Deep Western U.S. Conditions. In Proceedings of the $3^{\text {rd }}$ International Workshop on Coal Pillar Mechanics and Design, Morgantown WV, July 26, pp. 47-57.

54. Zipf, R.K. 1992. MULSIM/NL Theoretical and programmer's Manual. Bureau of Mines IC 9321, 58 pp.

55. Whittaker, B.N. and R.C. Frith. 1987. Aspects of Chain pillar Design in relation to Longwall Mining. In Proceedings of the $6^{\text {th }}$ International Conference on Ground Control in Mining, West Virginia University, Morgantown, WV, July, pp. 172-182.

56. Wilson, A.H. 1982. The Stability in Longwall Mining. State of the Art in Ground Control in Longwall Mining and Mining Subsidence, AIME, pp 89-95. 


\section{Appendix A}

Table A.1 Stress measurement case histories where multiple stress changes were monitored (Colwell et al., 1999).

\begin{tabular}{|c|c|c|c|c|c|c|}
\hline $\begin{array}{c}\text { Mine } \\
\text { Name }\end{array}$ & $\begin{array}{c}\text { Depth of } \\
\text { Cover (ft) }\end{array}$ & $\begin{array}{c}\text { Panel } \\
\text { Width (ft) }\end{array}$ & $\begin{array}{c}\text { Mining } \\
\text { Height (ft) }\end{array}$ & $\begin{array}{c}\text { Entry } \\
\text { Width }\end{array}$ & $\begin{array}{c}\text { Pillar } \\
\text { Width(ft) } \\
\text { (c-c) }\end{array}$ & $\begin{array}{c}\text { Locati } \\
\text { on }\end{array}$ \\
\hline AU-1 & 869 & 656 & 8 & 17 & 148 & AU \\
\hline AU-2 & 410 & 902 & 12 & 16 & 115 & AU \\
\hline AU-3 & 427 & 656 & 10 & 17 & 98 & AU \\
\hline AU-4 & 591 & 427 & 10 & 16 & 102 & AU \\
\hline AU-5 & 1558 & 656 & 8 & 16 & 138 & AU \\
\hline AU-6 & 787 & 476 & 10 & 16 & 115 & AU \\
\hline
\end{tabular}

Table A.2 Stress measurement case histories where only the final full side-abutment stress change profiles were provided.

\begin{tabular}{|c|c|c|c|c|c|c|}
\hline $\begin{array}{c}\text { Mine } \\
\text { Name }\end{array}$ & $\begin{array}{c}\text { Depth of } \\
\text { Cover (ft) }\end{array}$ & $\begin{array}{c}\text { Panel } \\
\text { Width (ft) }\end{array}$ & $\begin{array}{c}\text { Mining } \\
\text { Height (ft) }\end{array}$ & $\begin{array}{c}\text { Entry } \\
\text { Width }\end{array}$ & $\begin{array}{c}\text { Pillar } \\
\text { Width(ft) } \\
\text { (c-c) }\end{array}$ & $\begin{array}{c}\text { Locati } \\
\text { on }\end{array}$ \\
\hline AU-7 & 1329 & 820 & 8 & 16 & 160 & AU \\
\hline AU-8 & 1683 & 745 & 10 & 16 & 164 & AU \\
\hline AU-9 & 1198 & 820 & 12 & 16 & 157 & AU \\
\hline AU-10 & 1673 & 778 & 10 & 20 & 213 & AU \\
\hline US-1 & 1950 & 640 & 6 & 20 & $50,100,50$ & US \\
\hline US-2 & 2050 & 600 & 6 & 20 & $40,140,40$ & US \\
\hline
\end{tabular}


Table A.3 Supplementary field measurement data (Mark, 1992; Colwell et al., 1999).

\begin{tabular}{|c|c|c|c|c|c|c|c|}
\hline $\begin{array}{c}\text { Mine } \\
\text { Name }\end{array}$ & $\begin{array}{c}\text { Depth of } \\
\text { Cover } \\
\text { (ft) }\end{array}$ & $\begin{array}{c}\text { Panel } \\
\text { Width } \\
\text { (ft) }\end{array}$ & $\begin{array}{c}\text { Mining } \\
\text { Height } \\
\text { (ft) }\end{array}$ & $\begin{array}{c}\text { Entry } \\
\text { Width } \\
\text { (ft) }\end{array}$ & $\begin{array}{c}\text { Pillar } \\
\text { Width(ft) } \\
\text { (c-c) }\end{array}$ & $\begin{array}{c}\text { Locat } \\
\text { ion }\end{array}$ & $\begin{array}{c}\text { Abutment } \\
\text { Angle } \\
\text { (Deg.) }\end{array}$ \\
\hline Mine D-1 & 760 & 1000 & 5 & 18 & 60,60 & US & 18 \\
\hline Mine A-2 & 520 & 470 & 6.5 & 16 & 50,110 & US & 25 \\
\hline Mine E-3 & 630 & 500 & 11 & 18 & 90,90 & US & 20 \\
\hline Mine B-2 & 650 & 600 & 6.5 & 18 & 63,63 & US & 23 \\
\hline Mine B-3 & 600 & 600 & 6.5 & 18 & 98,38 & US & 10 \\
\hline Mine B-4 & 455 & 600 & 6.5 & 18 & 98,76 & US & 19 \\
\hline AU-11 & 853 & 676 & 8 & 16 & 115 & AU & 5 \\
\hline AU-12 & 476 & 656 & 8 & 16 & 82 & AU & 25 \\
\hline AU-13 & 525 & 640 & 10 & 16 & 82 & AU & 35 \\
\hline AU-14 & 1312 & 492 & 10 & 16 & 246,82 & AU & 18 \\
\hline AU-15 & 1312 & 492 & 10 & 16 & 82 & AU & 10 \\
\hline AU-16 & 427 & 656 & 10 & 16 & 82 & AU & 45 \\
\hline AU-17 & 558 & 837 & 11 & 16 & 82 & AU & 29 \\
\hline AU-18 & 525 & 656 & 10 & 16 & 82 & AU & 33 \\
\hline AU-19 & 1181 & 344 & 9 & 16 & 217 & AU & 9 \\
\hline AU-20 & 1476 & 466 & 9 & 16 & 92,43 & AU & 6 \\
\hline AU-21 & 853 & 738 & 8 & 16 & 79 & AU & 5 \\
\hline AU-22 & 591 & 640 & 10 & 16 & 98 & AU & 8 \\
\hline
\end{tabular}

